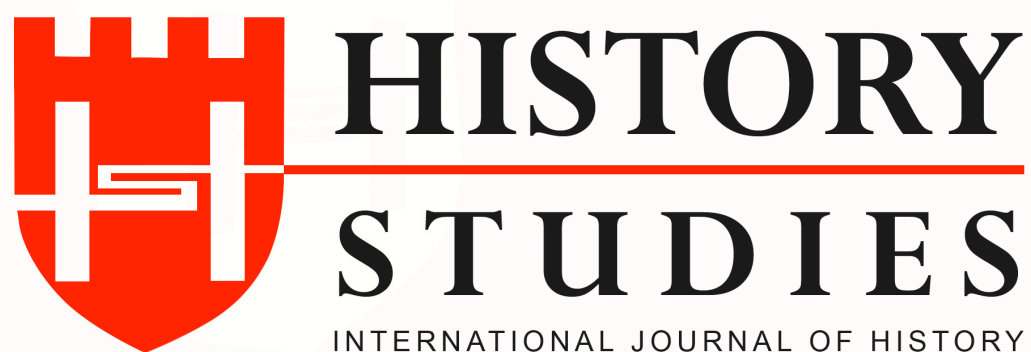

ISSN: 13094173 (Online) 1309 - 4688 (Print)

Volume 11 Issue 2, A tribute to Prof. Dr. Mehmet Ali ÜNAL, April 2019

DOI Number10.9737/hist.2019.733

Araștırma Makalesi

Makale Geliş Tarihi: 28.02.2019 - Kabul Tarihi: 03.04.2019

Atıf Künyesi: Mehmet Evsile, “TBMM Zabıtlarına Göre Cumhuriyet Döneminde Eğitim Hizmetleri (1923-1950)",

History Studies, 11/2, Nisan 2019, s. 621-654

\title{
TBMM Zabıtlarına Göre Cumhuriyet Döneminde Eğitim Hizmetleri (1923-1950)
}

Educational Services in the Republican Period According to the Turkish Grand National Assembly Records (1923-1950)

\author{
Prof. Dr. Mehmet EVSİLE \\ ORCID No: 0000-0001-5289-8703 \\ Amasya Üniversitesi Fen-Edebiyat Fakültesi
}

\begin{abstract}
Öz: Türkiye Cumhuriyeti döneminde gerçekleștirilen inkılâp hareketleri içerisinde en bașarıll olanlardan biri, eğitim alanında yapılanlar olmuştur. Eğitimin birleştirilmesi, harf inkılâbl ve her kademede yeri eğitim kurumları oluşturulmuştur. Temel eğitim ve üniversitelerin yanında, meslekî eğitim, dinî eğitim ve güzel sanatlar eğitimi için kurumsal düzenlemeler yapılmıştır. Okul çağındaki nüfusun dışında kalan yetişkin eğitimi için de "Millet Mektepleri", "Halk Mektepleri", "Gece Kurslart" açılarak halka okuma ve yazma ögretilmiştir. 1928-1935 yılları arasında bu kurumlardan 2.500.000 vatandaş eğitim almıştır. Örgün eğitim sahasında Köy Enstitüleri, şehirler için Halkevi ve Halk Odalar ile eğitim hizmetleri zenginleş̧tirilmiştir. Bütün bu faaliyetlerin sonunda 1924 yllında yüzde 2-3 olarak ifade edilen okuryazar oranı 1927 yllında yüzde 11, 1935 yllında yüzde 20,4, 1947 yllında yüzde 36,9 ve 1950 yllında yüzde 40 olmuştur. 1950 yllında 17.000 ilkokul, 1.625 .000 öğrenci; 215 ortaokul, 60.000 öğrenci saylsina ulaşılmıştır. Millî Eğitim Bakanlığına bağlı olarak sanat okulları, akşam erkek sanat okulları, kız enstitüleri, akşam kız sanat okulları, klz ve erkek öğretmen okullarl, ticaret ortaokulu ve liseleri, yapı ustası, terzilik ve kürkçülük gibi meslek okulları ile imam hatip okulları açılmıştır. Bu makalemiz, Türkiye Büyük Millet Meclisi Tutanaklarındaki konu ile ilgili konuşma metinleri esas alınarak hazırlanmıştır. Basılı eserlerden de faydalanılmıştır.
\end{abstract}

Anahtar Kelimeler: Türkiye Cumhuriveti, Eğitim İnkılâbı, Eğitim Hizmetleri, Eğitim Kurumları, Yetişkin Ĕgitimi, Dinî Ĕgitim, Meslekî Ĕ̈itim.

Abstract. The most important successful refoms realized in the Turkish Republic period is the reform realized on the education services. The education system was united to each other, the alphabet was changed and new educational institutions were esatblished. Besides the fundamental education institutions and universities, new regulations were made for occupational, theological and art educations. New establishments such as "National Shools", "Public Schools" and "Eveninng Courses" were organized for the adults who could not opportunity to attend schools and these people were taught how to read and write. About 2.500 .000 citizens were educated in these establishments between the years 1928 and 1935. The educational institutions were enriched through "Village Institutions" for villagers and "Public House and Public Rooms" for the people who lived in cities. At the end of these efforts, the literacy rate expressed as $2-3 \%$ in 1924 increased to $11 \%$ in 1927, 20,4\% in 1935, 36,9\% in 1947 and 40\% in 1950. The number of students attending 17.000 primary schools was 1.625 .000 and 60.000 students started to attend 215 secondary schools. Also in the following period, art schools, evening art schools for male, girls' institutions, evening art schools for female, male and female teacher training schools, occupational schools to train tailors, construction experts and fur sewing and theological schools were established under the Ministry of National Education.This study was carried on through the records of the speeches given in the Turkish Grand Assembly related to the mentioned subject. The printed materials were also used for the article.

Keywords: Turkish Republic, Education Services, Educational Institutions, Adult Education, Theological Education, Occupational Education. 


\section{Giriş}

Eğitim sahasında, devletin öncülüğ̈̈ ve sorumluluk üstlenme geleneği, Türk tarihinin ilk dönemlerinden itibaren görülmektedir. Gerek Selçuklu gerekse Osmanlı döneminde eğitimde devletin öncülüğ̈̈nü görmek mümkündür ${ }^{1}$.

Osmanlı Devleti, kuruluşundan itibaren farklı eğitim modelleri uygulamıştır. 1299-1773 yılları arasında en yaygın ve güçlü eğitim kurumları, medreseler olmuştur. Medreseler, 1924 yılına kadar varlıklarını sürdürmüşler, ancak gelişen dünya şartlarına göre kendilerini yenileyememişlerdir. Bunlardan başka azınlık çocuklarının üst seviyede bürokrat olarak yetişmelerini sağlayan Enderun Mektebi dikkat çekmektedir. İlköğretim, 19. yüzyıl sonuna kadar basit bir seviyede kalmıştır. İlkokuldan sonraki eğitim kademelerinde sadece erkek nüfusun eğitim aldığı görülmektedir. Bu dönemde eğitimin temel amacı dinîdir, nakilci ve ezberci bir eğitim modeli uygulanmıştır.

1773-1839 döneminde Mühendishane-i Bahrî-i Hümâyûn, Mühendishane-i Berrî-i Hümâyûn gibi askerî okullar açılmaya başlanmıştır. Bu okullarda Fransızca, İngilizce gibi batı dilleri de okutulmuş, yurt dışına öğrenci gönderilmeye başlanmıştır.

Tanzimat döneminde Maarif-i Umumiye Nizamnâmesi yayınlanarak (1869), eğitimin, devleti felâkete gitmekten kurtaracak tek vasıta olduğu kabul edilmiştir. Bu dönemde yeni anlayışlara göre ders kitapları yazılmaya başlanmıştır. Medrese dışında idadî, sultanî ve teknik eğitim okulları yoğun olarak İstanbul ve belli ölçülerde İstanbul dışında da açılmaya başlanmıştır. Türkçe, eğitim dili olarak kabul edilmiştir.

Meşrutiyet dönemlerinde ilköğretimden yüksek öğretime kadar olan eğitim kurumlarında, önceki dönemlerdeki gelişmeler devam etmiştir. Meslekî ve teknik alanlarda yeni okullar açılmıştır ${ }^{2}$. Ancak yabancı okullar da ciddî anlamda yaygınlık göstermeye başlamıştır ${ }^{3}$.

Eğitim alanında gerçekleştirilen faaliyetler, Osmanlı Devleti'nin yıkılışına engel olamadığı gibi, çağın şartlarına da ayak uyduramamıştır. Çok sayıdaki eğitim almış kişilerin yanında, eğitimin halka ulaşması ve yaygınlaşması mümkün olamamış; okur yazar oranları çok küçük rakamlarda kalmıştır.

\section{1-Eğitim Sistemi}

13 Mart 1913 tarihli İdare-i Umumiye-i Vilâyat Kanunu Muvakkati'nin 79. maddesi, Vilâyet Hususî İdarelerine ilköğretimin temini için genel ve gezici ilköğretim okulları, ortaokullar, öğretmen okulları, halkın eğitimi için gece okulları açmak ve bunları yönetmek görevi vermiştir ${ }^{4}$. 2 Şubat 1948 tarihinde Resmî Gazetede yayınlanan 5166 sayılı Özel idarelerden aylık alan ilkokul öğretmenlerinin kadrolarının Millî Eğitim Bakanlığg teşkilâtına alınması hakkında kanun yürürlüğe girinceye kadar ilköğretim hizmetleri Vilâyet Hususî İdareleri tarafından yürütülmüştür ${ }^{5}$. İlköğretimin dışındaki okullar ve öğretmen maaşları, Millî Eğitim Bakanlığına bağlı idi. Bunun sonucu olarak eğitim giderleri ve öğretmenlerin maaşları iki kaynaktan karşılanıyordu. Bu kaynakların birincisi devletin bütçesi (Muvazene-i Umumiye), diğeri de illerin hususî bütçeleriydi. Maarif Nezaretinin giderleri, Darülfünun ve ona bağlı

\footnotetext{
${ }^{1}$ Nurdan Kalaycı, Cumhuriyet Döneminde İlkögretim Hükümet Programları ve Uygulamalar, Milli Eğitim Gençlik ve Spor Bakanlığı Yayınları: 762, İstanbul 1968, s. 7-8.

${ }^{2}$ Yahya Akyüz,Türk Ĕ̈itim Tarihi, Kültür Koleji Yayınları, İstanbul, 1993, s .54-275.

${ }^{3}$ İlknur Polat Haydaroğlu, Osmanlı Imparatorluğu'nda Yabancı Okullar, Kültür Bakanlığı Yayını, Ankara, 1990, s.101-194.

${ }^{4}$ Yenal Ünal, "İdare-i Umumiye-i Vilâyet ve İdare-i Hususiye-i Vilâyet Kanunları”, Tarih Okulu, Yaz 2009,

Sayı: IV, s.90.

${ }^{5}$ T.C. Resmî Gazete, 2 Şubat 1948, Sayı:6821, s.13557.
}

\section{History Studies}


kuruluşların, yüksekokulların, orta dereceli okulların (sultanîlerin) giderleri de devlet bütçesinden karşılanmıştır. Vilayetteki ilkokulların, idadîlerin, darülmuallimînlerin(Erkek Öğretmen Okulu) her türlü giderleri ise hususî bütçeden karşılanmaktaydı ${ }^{6}$.

3 Mart 1924 tarih ve 430 sayılı Tevhîd-i Tedrîsât Kanunu ile bütün okullar Millî eğitim Bakanlığına bağlanmış ve medreseler kapatılmıştır. Bu şekilde eğitimin lâikleştirilmesi ve demokratikleştirilmesi yoluna gidilmiştir ${ }^{7}$. 1 Kasım 1928 tarih ve 1353 sayılı Yeni Türk Harflerinin Kabul ve Tatbiki hakkında Kanun ile de yeni harflerin halka öğretilmesi için çok geniş bir okuma yazma faaliyeti başlatılmış; ders kitapları, sözlükler, basılı resmî yayınlar yeniden yazılmıştır ${ }^{8}$.

\section{2-Okullar}

\section{a-İlkokullar}

Osmanlı Devleti'nden devralınanlarla Cumhuriyet döneminde çeşitli yıllara ait okul sayıları hakkında verilen bilgilerden istatistik sonuçlar çıkarılabilir. Osmanlı döneminde, bütün ülkede 3400 kadar okul ve bu okullara giden toplam 223.000 öğrenci olduğu iddia edilmiştir 9 . 1923 yılında resmî ilkokulların sayısı 4770'e, öğrenci sayısı 337.618'e yükselmiştir ${ }^{10} .1924$ yılında 5952 okulda 12.982 ögretmen ve 384.315 ögrenci ${ }^{11}, 1926$ yllında 5655 ilkokul, 10.593 öğretmen, 346.459 öğrenci; 1927 yılında 5887 ilkokul, 11.776 öğretmen, 385.455 öğrenci tespit edilmiştir $^{12} .1930$ y1lında okul sayıs1 6672, öğretmen sayıs1 16.229 , öğrenci sayıs1 479.442 olmuştur. 1924 yılında ilkokullara ayrılan ödenek 5.810.630 liradan 1930 yılında 15.921.343 liraya çıkmıştır ki artış oranı yüzde $170{ }^{\prime} \mathrm{dir}^{13} .1934$ yılında ilköğretimde öğretmen sayısı 14.000 'e, öğrenci sayıs1 560.000'e ulaşmıştır ${ }^{14}$. 1936 yılında ilköğretimdeki öğretmen sayıs1 13.384, öğrenci sayısı 1.850 .000 olmuştur ve ilköğretim çağındaki çocukların, şehirlerde yüzde $68^{\prime} \mathrm{i}$; köylerde yüzde $25^{\prime} \mathrm{i}$ okullara alınmıştır ${ }^{15}$. 1950 yılında toplam 17.000 ilkokul, 1.625 .000 öğrenci bulunduğu ve bu okullardan 133.000 mezun verildiği, Millî Eğitim Bakanı tarafından açıklanmışıır ${ }^{16}$.

\section{b-Ortaokullar}

1923 yılında72 orta okulda 5905 öğrenci mevcuttu ${ }^{17} .1936$ y1lında ortaokullarda toplam 75.229 öğrenci okumakta iken, bu rakam 1937 yılında 90.000’i aşmıştır. Bu yılda Bafra, Bakırköy, Bandırma, Beykoz, Çorlu, Fatih, İnebolu, İstanbul-Süleymaniye, Kasımpaşa, Üsküdar, Karaköse (Ağrı) ve Muş’ta birer ortaokul açılmıştır ${ }^{18} .1939$ yılında AnkaraHamamönü, Kırşehir, İstanbul-Karagümrük ve Nişantaşı'nda ortaokullar açılarak ortaokul sayısı 194'e ulaşmıştır ${ }^{19} .1943$ yılında, ortaokul sayısı 209, öğretmen sayısı 3.000 olmuştur $^{20}$.

\footnotetext{
${ }^{6}$ Erdoğan Başar, Millî Eğitim Bakanlarının Eğitim Faaliyetleri (1920-1960),Millî Eğitim Basımevi, Ankara, 2004, s.62.

${ }^{7}$ Yahya Akyüz, Türk Eğitim Tarihi, Kültür Koleji Yayınları, İstanbul, 1993, s .283.

${ }^{8}$ Yahya Akyüz, a.g.e., s. 289.

${ }^{9}$ Sadri Maksudî Bey (Şebinkarahisar), 27.05.1934, TBMM,TBMM ZC (4. Dönem), Cilt:22, s.321.

${ }^{10}$ Maarif Vekili Mustafa Necati Bey (İzmir), 22.04.1928, TBMM,TBMM ZC (3. Dönem), Cilt:3, s.201.

${ }^{11}$ Refik Şevket Bey (Manisa), 25.06.1932, TBMM,TBMM ZC (4. Dönem), Cilt:9, s.313.

${ }^{12}$ Maarif Vekili Mustafa Necati Bey (İzmir), 25.06.1932, TBMM,TBMM ZC (4. Dönem), Cilt:9, s.313.

${ }^{13}$ Refik Şevket Bey (Manisa),25.06.1932, TBMM,TBMM ZC (4. Dönem), Cilt:9, s.313.

${ }^{14}$ Maarif Vekili Hikmet Bey (Manisa), 29.05.1934, TBMM,TBMM ZC (4. Dönem), Cilt:22, s.442.

${ }^{15}$ Maarif Vekili Saffet Arıkan (Erzincan), 26.05.1936, TBMM,TBMM ZC (5. Dönem), Cilt:11, s.245.

${ }^{16}$ Millî Eğitim Bakanı Tahsin Banguoğlu (Bingöl), 20.02.1950, TBMM,TBMM TD (8. Dönem), Cilt:24, s.849.

${ }^{17}$ Millî Eğitim Bakanı Hasan Âli Yücel (İzmir), 24.12.1945, TBMM,TBMM TD (7. Dönem), Cilt:20, s.337.

${ }^{18}$ Maarif Vekili Saffet Arıkan (Erzincan), 26.05.1937, TBMM,TBMM ZC (5. Dönem), Cilt:18, s.257.

${ }^{19}$ Maarif Vekili Hasan Âli Yücel (İzmir), 25.05.1939, TBMM,TBMM ZC (6. Dönem), Cilt:2, s.266.
}

\section{History Studies}


1945 yılında ortaokul sayısı 163, ortaokullardaki öğrenci sayısı 64.000' dir $^{21} .1947$ y1lında 177 ortaokul, 56.775 öğrenci mevcuttur ${ }^{22} .1950$ yllında 215 ortaokulda, 60.000 öğrenci olduğu açıklanmıştır ${ }^{23}$.

\section{c-Liseler ve Meslek Okulları}

1923 y1lında23 lise,1241 öğrenci bulunmakta idi ${ }^{24}$.Lise sayısı 1932 yılında 30 iken 1938 y1lında 36'ya çıkarılmıştır ${ }^{25} .1945$ yılında lise sayısı52, öğrenci sayıs121 bindir ${ }^{26} .1946$ yılında 53 lise ve buralardan mezun olanların sayısı 5000'e yaklaşmışı ır ${ }^{27}$.

1937 yılı itibarıyla Millî Eğitim Bakanlığına bağlı erkek sanat okulları, akşam erkek sanat okulları, kız enstitüleri, akşam kız sanat okulları, kız erkek öğretmen okulu, orta ticaret okulları, birincive ikinci devreli ticaret liseleri, akşam ticaret okulları, yapı ustası okulu, terzilik ve kürkçülük okulu gibi meslek okulları bulunmaktadır. Erkek Sanat Okullarında 200 öğretmen ve 2126 ögrenci mevcuttur. Akşam Erkek Sanat Okullarında 160 kadar işçi çalışmaktadır. Ankara, İstanbul, Üsküdar, İzmir, Bursa, Kadıköy ve Adana'da açılmış olan 7 adet Kız Enstitüsünde 1460 öğrenci mevcuttur. Adana, Afyon, Diyarbakır, Edirne, Erzurum, Konya, Trabzon'da açılmış olan 7 adet Akşam Kız Sanat Okulunda 6980 öğrenci mevcuttur. Sadece Ankara'da açılmış olan Kız Meslek Öğretmen Okulu'ndan 1937 yılında 37 öğrenci mezun olmuştur. İzmir ve Ankara'daki 2 Ticaret Lisesi ile Adana, Samsun ve Trabzon'daki Orta Ticaret Okulu'nda 935 öğrenci mevcuttur ${ }^{28}$.

1950 yılı itibarı ile kız enstitülerinde ve akşam sanat okullarında 35.000 kadar öğrencinin iş öğrendiği tespit edilmiştir ${ }^{29}$. Bu dönemde 1924 yılından 1939 yılına kadar İstanbul'da açılan meslek ve ihtisas mekteplerinin tam listesi ve ayrıntılı açıklamalar, Osman ERGIN'in Türk Maarif Tarihi isimli eserinde mevcuttur ${ }^{30}$.

\section{d-İmam Hatip Mektepleri ve İmam Hatip Kursları}

Tevhid-i Tedrisat Kanunu'nun din görevlisi eğitimini düzenleyen 4. maddesi medreselerin kapatılmasına karşılık, imamlık ve hatiplik gibi dinî hizmetlerin görülebilmesi için ayrı okullar açılmasını öngörüyordu. Kanunda öngörülen bu okullar, 1924 yılında İmam Hatip Mektepleri adı altında 29 merkezde açıldı ${ }^{31}$. Okullar, 4 yıllık ortaöğrenim seviyesinde idi. İmam Hatip Mektepleri 1930'da öğrenci azlığı nedeniyle kapatılmıştır. 1949 yılında ortaokul mezunu askerliğini yapmış kimselerin alındığı 10 ay süreli İmam Hatip Kursları açılarak din hizmeti

HISTORY

ST UDIES

624

Volume 11

Issue 2

A tribute to

Prof. Dr.

Mehmet Ali

ÜNAL

April

2019

\footnotetext{
${ }^{20}$ Hikmet Turan Dağlıoğlu (Antalya), 26.05.1943, TBMM,TBMM ZC (7. Dönem), Cilt:2, s.239.

${ }^{21}$ Millî Eğitim Bakanı Hasan Âli Yücel (İzmir); 24.12.1945, TBMM,TBMM TD (7. Dönem), Cilt:20, s.337.

${ }^{22}$ İsmail Hakkı Baltacıŏlu (Kırşehir), 29.12.1947, TBMM,TBMM TD (8. Dönem), Cilt:8, s.590.

${ }^{23}$ Millî Eğitim Bakanı Tahsin Banguoğlu (Bingöl), 20.02.1950, TBMM,TBMM TD (8. Dönem), Cilt:24, s.850.

${ }^{24}$ Millî Eğitim Bakanı Hasan Âli Yücel (İzmir), 24.12.1945, TBMM,TBMM TD (7. Dönem), Cilt:20, s.337.

${ }^{25}$ Dr. Osman Şevki Uludağ (Konya), 26.05.1938, TBMM,TBMM ZC (5. Dönem), Cilt:25, s.221.

${ }^{26}$ Millî Eğitim Bakanı Hasan Âli Yücel (İzmir), 24.12.1945, TBMM,TBMM TD (7. Dönem), Cilt:20, s.337.

${ }^{27}$ Millî Eğitim Bakanı Reşat Şemsettin Sirel (Sivas), 24.12.1946, TBMM,TBMM TD (8. Dönem), Cilt:3, s.465.

${ }^{28}$ Maarif Vekili Saffet Arıkan (Erzincan), 26.05.1937, TBMM,TBMM ZC (5. Dönem), Cilt:18, s.256-257.

${ }^{29}$ Millı̂ Eğitim Bakanı Tahsin Banguoğlu (Bingöl), 20.02.1950, TBMM, TBMM TD (8. Dönem), Cilt:24, s.851.

${ }^{30}$ Osman Ergin,Türk Maarif Tarihi, Cilt:5, İstanbul, 1977, s.2124-2164.

${ }^{31} \mathrm{Bu}$ okulların açıldığı merkezler ve öğrenci sayıları hakkında ayrıntılı bilgi için bkz. Mustafa Öcal;"“Cumhuriyet Döneminde Türkiye'de Din Eğitimi ve Öğretimi”, Uludağ Üniversitesi Illâhiyat Fakültesi Dergisi, Cilt:7, Say1:7, s.132-134.
}

\section{History Studies}


görevlisi yetiştirme uygulaması başladı. 1950 yılı itibarıyla on adet İmam Hatip Kursundan 50 öğrenci mezun olmuştur ${ }^{32}$.

\section{e-Köy Enstitüleri}

Köy Enstitüleri,17 Nisan 1940 tarihli ve 3803 sayılı kanunla kurulmuştur. Kuruluş amaçları şu şekilde tespit edilmiştir ${ }^{33}$ : “1940'da 6 yaşın üstündeki nüfusun yüzde 78'i okuryazar değildi. Köylerde bu oran yüzde 90'dl. Ayrıca köyler sağllk, temizlik, gelişme imkânlarından uzaktı. Bu yaygın bilgisizlikle daha etkili mücadele etmek, bunu yaparken köylerin sosyal ve ekonomik yapısında ögretmen ve ĕgitim kanalıyla düzenlemeler, gelişmeler sağlamak... İşte Köy Enstitüleri bu amaçla kuruldu. O zamana kadar mevcut öğretmen yetiştirme düzeninin neyi eksikti ve yeni bir öğretmen yetiştirme sistemi geliştirilmek isteniyordu? Mevcut eski düzen, nazarî eğitim yapan, ellerinde kalem, kitap ve yalnızca okuma ve yazma ve kitabî bilgiler ögretimi ile yetinen, köye gitmek, orada kalmak istemeyen, köylüye pek yararlı olmayan ögretmenler yetiştirmekle suçlanıyordu. Oysa artık köy kökenli, yalnızca köye yararlı olabilecek, nasırl ellerinde kalem ve kitaptan çok, kazma, kürek, çapa, băg makası, keser bulunan ögretmenler yetiştirilmeliydi. Köy Enstitülerinin kuruluş felsefesi budur."

1940-1948 yılları arasında ülkenin değiş̧ik bölgelerinde 21 tane Köy Enstitüsü açılmıştır. Köy Enstitüsü açılan yerler şunlardır ${ }^{34}$ : İzmir-Kızılçullu, Eskişehir-Çifteler, LüleburgazKepirtepe, Kastamonu-Gölköy, Malatya-Akçadağ, Antalya-Aksu, Lâdik-Akpınar, AdapazarıArifiye, Vakfıkebir-Beşikdüzü, Kars-Cılavuz, Bahçe-Düziçi, Isparta-Gönen, BalıkesirSavaştepe, Kayseri-Pazarören, Ankara-Hasanoğlan, Konya Ereğli-İvriz, Yıldızeli-Pamukpınar, Erzurum-Pulur, Ergani-Dicle, Aydın-Ortaklar, Van-Erciş.

Volume 11

Issue 2

A tribute to

Prof. Dr.

Mehmet Ali

ÜNAL

April

2019

Şubat 1954'te yayınlanan 6234 sayılı kanunla, Köy Enstitüleri, İlköğretmen Okulları ile birleştirilerek sona erdirilmiştir. Köy Enstitülerinden toplam 15.000 kadar öğretmen,2.000 kadar sağlıkçı yetişmiştir ${ }^{35}$.

Köy Enstitüleri ve buralardan mezun olan öğretmenler konusunda, Türkiye Büyük Millet Meclisi genel kurulunda, çeşitli görüşler dile getirilmiştir. Bunlardan birinde, Köy Enstitülerinin, Cumhuriyetin, Türk milletine armağan ettiği en güzel hediye olduğu ${ }^{36}$; diğerinde, kalkınmanın temeli olduğu vurgulanarak şu ifadelere yer verilmiştir" : "Bunların en mühim vazifeleri köy ögretmenleri yetiştirmek olduğu gibi, köylülerin işlerine yarayacak birçok meslek erbabını da yetiştirmektir. Bu köy öğretmenleri tabii köylülerin çocuklarını okutmak için uğraştıkları gibi köylerin kültürel terakkîlerine yardım için kanunî vazifeler almuşlardır. Bir taraftan Köy Enstitüleri bu yolda çalışırken diğer taraftan da yine köylerin kalkınması için köy kursları açmıştır." Millî Eğitim Bakanı Reşat Şemsettin SİRER de, köy kalkınması yolunda Köy Enstitüsü mezunu öğretmenlerin önemli görevler üstleneceğini söylemiştir ${ }^{38}$. Köy Enstitülerinin idealist oldukları hususu da şöyle dile getirilmiştir": "Köy Enstitüleri bu memleketin evlâdıdır, kamutayın çocuklarıdır. Iyidirler, temizdirler, ülkücüdürler. Sizin kutsal

\footnotetext{
${ }^{32}$ Millî Eğitim Bakanı Tahsin Banguoğlu (Bingöl), 20.02.1950, TBMM,TBMM TD (8. Dönem), Cilt:24, s.857.

${ }^{33}$ Yahya Akyüz, a.g.e., s.339.

${ }^{34}$ YahyaAkyüz, a.g.e., s.339.

${ }^{35}$ YahyaAkyüz, a.g.e., s.342.

${ }^{36}$ Hüseyin Ulusoy (Niğde), 25.05.1944, TBMM,TBMM TD (7. Dönem), Cilt:10, s.279-280.

${ }^{37}$ General Şefik Türsan (İçel), 26.05.1943, TBMM,TBMM ZC (7. Dönem), Cilt:2, s.240-241.

${ }^{38}$ Millî Eğitim Bakanı Reşat Şemsettin Sirer (Sivas), 24.12.1946, TBMM,TBMM TD (8. Dönem), Cilt:3, s. 460 .

${ }^{39}$ İsmail Hakk1 Baltacıŏlu (Kırşehir), 29.12.1947, TBMM,TBMM TD (8. Dönem),Cilt:8, s.591.
} 
davanıza ihanet edecek insanlar değillerdir. Yerli, münzevivak'alardan dolayı hiç kuşkulanmayalım. Millet yolunda çalışmaktadırlar."

Köy Enstitüsü mezunlarının köylülerle yaşadıkları sıkıntılar da olmuştur. Buna bir örnek, şu şekilde ifade edilmiştir ${ }^{40}$ : "Ellerinde mandolinle gezen bu gençlere mutaassıp bir köylü, için için kin besliyor ve siz diyor mektepte bunu ти ögrrendiniz? Ve tehevvürle elindeki mandolini alıp kırıyor. Şimdi bunun karşısında bir insan hüviyetinin, ruhiyatının göstereceği asabiyet ve infial yerine bu genç, -daha üçüncü sinıftadır- kemâl-i sükûnet ve sekinetle köylünün yüzüne bakıyor, siz haklısınız, sizin dediğiniz doğrudur diyerek ayrılıyor. Fakat bu genç, başka bir çareye müracaat ediyor. $O$ çare şudur: Diğer arkadaşlarını topluyor, ellerindeki sazlarla köyün meydanına geliyorlar, içlerinde söyleyenler de varmıs, onlar da halk türkülerini söylemeye başlıyorlar. Halkta derin bir alâka uyandırıyor. Bunların etrafindaki halka gittikçe büyüyor, bütün köy bu gençlerin etrafinda toplanıyor. Şimdi birkaç saat evvel büyük bir kusur işleyen köylü, evinin penceresini açmış, oradan bakmaktadır. Coşan köylü bir müddet sonra halay çekmeye başllyor, zeybek oynamaya geçiyor, tam kendini yaşlyor. O köylü bunu görünce, hemen merdivenden iniyor, doğru meydanın ortasına gidiyor. Bu, üçüncü sinıfta bulunan gencin ellerine sarllyyor, diyor ki, sen bana ne kadar çok yakınmışsın, sen de ne kadar bendenmişsin. Biraz evvelki hareketinden dolayı af diliyor ve mandolinin parasinı ödemeye çalışıyor."

Köy Enstitülerine köy çocuklarının alınmasının ve bunların daha sonra kendi köylerinde görev yapmalarının, Köy Enstitülerinden beklenen köylerin kalkınması amacına hizmet edemeyeceği şeklinde eleştiriler de olmuştur ${ }^{41}$. Bunların köylerde yaşadıkları sıkıntılardan örnekler de verilmiştir" ${ }^{42}$ "Köy Enstitüsünden mezun bir köy çocuğunun herhangi bir köye ögretmen olarak gittiğini düşünelim: Kafasında ve muallâklara birtakım güzel düşünceler, kararlar ve bilgiler bulunan 20 yaşlarında bir çocuk. Karşısında, içine kapanık, töreleri muhkem, imkânları kıt, sen salla bașını, ben bilirim ișimi diyen bir köy. Kim kimi eritecek, kim kime benzeyecek? Bu kararlart ve bilgileri köye yaymak ve benimsetmek için bu gence ne gibi kanunî tedbirler, ne gibi müeyyideler, ne yolda üstünlükler temin edilecektir. Bu gencin, bir müddet sonra zaten çocukken içinde büyüdüğ̈̈ köy şartlarına kendini bırakıvermesi, muhtarın kızı ile evlendikten sonra eski köy yaşayışına karışıvermesi ihtimalini önlemek için, onun azmi ve imanı ne ile desteklenecektir? Ne gibi selâhiyetleri, nasıl yardımcıları olacaktır?" Köy Enstitüsü mezunlarının köylerde yaşadıkları sıkıntılar hakkında diğer bir örnek de şöyledir ${ }^{43}$ : “14 milyon Türk köylüsünü 7'den 70'ine kadar yetiştirecek olan köy enstitüsü mezunlarl, artık hayata daha olgun bir şekilde atılmalıdır. Çok zaylf bir köy tahsilinden sonra köy enstitüsüne giden ögrenci mandolinden marangozluğa, sivacılıktan pedagojiye kadar ögrenir. Arkadaşlar beş senede bir adamın âlim, fazll, san'atkâr olmasina imkân yoktur. Ve şu zihniyeti bilmeleri lâzımdır ki, Türk köylüsü böyle yarım yamalak yetişenlerin bilgisine ihtiyaç gösterecek kadar aşağl seviyede değildir. Sonra bu gençler köye gidecekler, müsamere verecekler, artan zamanda da tarla sürüp kazancını sağlayacaktır. Fakat arkadaşlar, bu işler 24 saate sı̆̆maz. Ziraatçiler, veterinerler kasabalarda, merkezlerde masa başlarında bürokratik bir hayat yaşarken köyün sorumluluğunu böyle yarım yamalak yetişen gençlerin omuzlarına yüklemek ve bundan iyi bir netice beklemek herhalde doğru bir düşünce değildir. "

Köy Enstitüsü mezunlarının bilgi bakımından yetersiz oldukları Millî eğitim Bakanı tarafından da kabul edilmiştir. 1947 yılı itibarıyla 7.000 köy öğretmeni, eksikleri tamamlanmak

\footnotetext{
${ }^{40}$ M.Emin Ataç (Tekirdağ); 25.05.1944, TBMM,TBMM ZC (7. Dönem), Cilt:3, s.285.

${ }^{41}$ Millî Eğitim Bakanı Hasan Âli Yücel (İzmir), 24.12.1945, TBMM,TBMM TD (7. Dönem), Cilt:20, s.336.

${ }^{42}$ Behçet Kemâl Çağlar (Erzincan), 26.05.1943, TBMM,TBMM ZC (7. Dönem), Cilt:2, s.235.

${ }^{43}$ Nurettin Ünen (Çanakkale), 23.12.1946, TBMM,TBMM TD (8. Dönem), Cilt:3, s.398.
} 
üzere yeniden kurslara alınmışlardır ${ }^{44}$. Köy Enstitüsü mezunlarının yetersizliği hakkında başka tespitler de vardır" : "Köy Enstitüleri meselesi!... Fikir iyidir, realisttir, yerlidir, görüş parlaktır. Fakat hedefte biraz isabetsizlik vardır zannediyorum. Bu enstitüler ne yapmak istemiş? Marangoz, çiftçi ve demirci ögretmeni yetiştirerek, köyün ekonomik hayatını kalkındırmak istemiştir. Ne parlak fikir. Buna karşı gelinebilir mi? Fakat muvaffak olunamamıştır... Demircilik, marangozluk, davarcılık... Böyle nazarî dersler arasında mahdut ve dar bir tarlada, ne olduğu belli olmayan bir tarlada, daha çok nazarî ve pek az amelî olarak bel bellemek, çapa sallamak gibi bahçıvanlık ögrrenilmez. Gezdiğim köylerde, ilçelerde, demircilik tekniği, marangozluk tekniği bakımından köylerdeki ustalardan geridir. Ve onların seviyelerine ulaşmalarına imkân yoktur. Toprak ve bu gibi san'atlar öyle kolay kolay öğrenilir şeyler değildir."

Son olarak Köy Enstitüsü mezunlarının siyasete alet edildikleri eleştirileri de yapılmışıır ${ }^{46}$.

\section{f-Millet Mektepleri}

1 Kasım 1928 tarihinde gerçekleştirilen harf inkılâbından sonra, vatandaşlara yeni harflerle okuyup yazmayı öğretmek için 8 Kasım 1928 tarihinde Millet Mektepleri Yönetmeliği hazırlanmış, 11 Kasım 1928'de Bakanlar Kurulu tarafından onaylanmış ve 24 Kasım 1928 tarihli Resmî Gazete'de yayınlanarak yürürlüğe girmiştir ${ }^{47}$.

1935 yılına kadar faaliyet gösteren bu okulların çalışmalarından bazıları Türkiye Büyük Millet Meclisi genel kuruluna da yansımıştır. Buna göre, Arap harfleri bilen vatandaşlardan, 1928-1929 yılında 427.979 kişi, 1929-1930 yılında 396.484 kişi, 1930-1931 yılında 127.383 kişi millet mekteplerine devam etmek suretiyle yeni harfleri öğrenmiştir. Hiçbir lisan okuyup yazma bilmeyip, millet mekteplerinde okuma yazma öğrenenlerin miktarı 1928-1929 yılında 174.984 kişi, 1930-1931 yılında 39.779 kişi olmuştur ${ }^{48}$. 1928-1935 yılları arasında Millet Mekteplerinin şehir ve köylerde açılan bütün kademelerinde eğitim alan vatandaş sayısı 2.500 .000 'i geçmiş ${ }^{49}$; belge alan vatandaş sayısı 1.878 .676 'ya kadar ulaşmıştır ${ }^{50}$.

\section{g-Halk Mektepleri ve Gece Kursları}

Öğretmenler, gündüzleri görevlerini tamamladıktan sonra, geceleri de okuma yazma bilmeyen ve tahsil çağını geçirmiş olan halkın okutulmasıyla görevlendirilmişlerdir. 1928 yılı itibarıyla bu iş için bütçeye 12.000 lira tahsisat konmuş ve il özel idare bütçelerinden 100.000 lira halk mektepleri tahsisatı olarak ayrılmıştır. Bunlarla 100 halk mektebi açılmış ve buralarda toplam 45.000 genç eğitim almıştır ${ }^{51}$.

Gündüzleri ticaret hayatıyla geçirenlere, akşamları müsait zamanlarında kendilerine lâzım gelen bilgileri verecek ve onları işlerinde daha kuvvetli bir hale getirecek kurslar açılmıştır. 1928 y1lı itibarıyla bu kurslar 12 yerde açılmış ve 493 öğrenciye hizmet vermiştir ${ }^{52}$.

\footnotetext{
${ }^{44}$ Millî Eğitim Bakanı Reşat Şemsettin Sirer (Sivas). 29.12.1947, TBMM,TBMM TD (8. Dönem), Cilt:8,s.622.

${ }^{45}$ İsmail Hakkı Baltacıŏlu (Kırşehir), 23.12.1946, TBMM,TBMM TD (8. Dönem), Cilt:8, s.591.

${ }^{46}$ Eminittin Çeliköz (Balıkesir), 24.12.1946, TBMM,TBMM TD (8. Dönem), Cilt:3, s.441.

${ }^{47}$ Mustafa Albayrak, "Millet Mekteplerinin Yapısı ve Çalışmaları (1928-1935)", Atatürk Araştırma Merkezi Dergisi, Temmuz 1994, Cilt:X, Say1:29, s.472-473.

${ }^{48}$ Refik Şevket Bey (Manisa), 25.06.1932, TBMM,TBMM ZC (4. Dönem), Cilt:9, s.313.

${ }^{49}$ Refik Şevket Bey (Manisa), 25.06.1932, TBMM,TBMM ZC (4. Dönem), Cilt:9, s.321.

${ }^{50}$ M.Albayrak,a.g.makale, s.480-482.

${ }^{51}$ Maarif Vekili Mustafa Necati Bey (İzmir), 22.04.1928, TBMM,TBMM ZC (3. Dönem), Cilt:3, s.202-203.

${ }^{52}$ Maarif Vekili Mustafa Necati Bey (İzmir), 22.04.1928, TBMM,TBMM ZC (3. Dönem), Cilt:3, s.205.
} 
Köylerde de, vatandaşların okul sonrası bilgilerini artırmak için okuma odaları açılmıș ve buralara kitaplar gönderilmiştir ${ }^{53}$.

Ayrıca 1949 yılında, İzmir'de bir Dilsizler, Körler, Sağırlar Okulu bulunduğu ve bu yılki talebe kadrosu 150 olduğu dile getirilmiştir ${ }^{54}$.

\section{h-Üniversiteler}

2252 sayılı ve 31 Mayıs 1933 tarihli İstanbul darülfünununun ilgasına ve Maarif vekâletince yeni bir Üniversite kurulmasına dair kanun, 6 Haziran 1933 tarihinde yayınlanarak yürürlüğe girmiştir ${ }^{55}$. Bu kanun gereğince Darülfünun kapatılarak yerine, Millî Eğitim Bakanlığına bağlı olarak İstanbul Ǘniversitesi kurulmuştur. İstanbul Üniversitesinden sonra kurulan yüksek öğretim kurumları olan Yüksek Ziraat Enstitüsü (1933), İstanbul Teknik Üniversitesi (1944), Ankara Üniversitesi (1946) ile enstitüler ve yüksek okullar ülkemiz yükseköğretim yapısının temelini oluşturmuştur ${ }^{56}$.

Üniversitenin gelişmesi ve öğrencilerin durumları zaman zaman Türkiye Büyük Millet Meclisi genel kurulunda ifade edilmiştir. 1934 yılında üniversitede 300 kadar öğretim elemanı ve 3500 kadar öğrenci olduğu Maarif Vekili tarafından dile getirilmiştir ${ }^{57}$. 1938-1939 yılında 6 fakülte ve 3 Yüksek Okulda 282 profesör ve doçent, 247 asistan, okutman ve ilmî yardımc1 varken, bu rakamlar 1945-1946 y1lında 594 profesör ve doçent, 425 asistan, okutman ve yardımcı olarak tespit edilmiştir ${ }^{58} .1950$ yılı itibarıyla üniversitelerde toplam 20.000 , diğer yükseköğretim kurumlarında da 5.000 olmak üzere toplam 25.000 yüksek öğretim öğrencisi bulunduğu bildirilmiştir ${ }^{59} .1943$ yılında bir profesör maaşının 60-70 lira, bir doçent maaşının 35-40 lira olduğu görülmektedir ${ }^{60}$.

Üniversiteye yüklenen misyon, Kültür Bakanı Saffet ARIKAN tarafından, "memleket davalarının ideolojisini anlayacak, anlatacak, nesilden nesile yaşayacak fert ve kurumlar yaratmak gibi çok esasl bir vazife" olarak ifade edilmiştir ${ }^{61}$. İstanbul Üniversitesi'nin, kuruluşunun 10. yılında büyük tekâmül gösterdiği ve arzu edilen hedeflere doğru gittiği dile getirilmiştir ${ }^{62}$.

İstanbul'dan sonra Ankara'da Hukuk Fakültesi ile Dil ve Tarih Coğrafya Fakültesinin açılmasıyla öğrencilerin barınması konularında sıkıntılar görülmeye başlanmıştır. Evlerinde kalan öğrencilerin dışında, diğer şehirlerden gelip yurtlarda ve otellerde kalan öğrencilerin mağduriyetler yaşadıkları dile getirilmiştir. Bu öğrencilerin toplamının 3.000 olduğu, ancak Ankara'nın imkânlarının bu yükü kaldıramadığ 1 ifade edilmiştir ${ }^{63}$. İstanbul'daki yüksek öğretim öğrencileri için yurt imkânlarının biraz daha iyi olduğu görülmektedir ${ }^{64}$.

\footnotetext{
${ }^{53}$ Maarif Bakanı Abidin Özmen (Aydın), 25.05.1935, TBMM,TBMM ZC (5. Dönem), Cilt:3, s.260.

${ }^{54}$ Mustafa Reşit Tarakçıŏlu (Trabzon), 22.05.1949, TBMM, TBMM TD (8. Dönem), Cilt:16, s.645.

${ }^{55}$ T.C. Resmî Gazete, 6 Haziran 1933, Say1:2420, s.2635.

${ }^{56}$ Yücel Namal-Tunay Karakök, “Atatürk ve Üniversite Reformu (1933)”, Yükseköğretim ve Bilim Dergisi, Cilt:1, Say1:1, Nisan 2011, s. 35.

${ }^{57}$ Maarif Vekili Hikmet Bey (Manisa), 29.05.1934, TBMM,TBMM ZC (4. Dönem), Cilt:22, s.442.

${ }^{58}$ Millî Eğitim Bakanı Hasan Âli Yücel (İzmir), 24.12.1945, TBMM,TBMM TD (7. Dönem), Cilt:20, s.339.

${ }^{59}$ Millî Eğitim Bakanı Tahsin Banguoğlu (Bingöl), 20.12.1950, TBMM,TBMM TD (8. Dönem), Cilt:24, s.852.

${ }^{60}$ Suut Kemâl Yetkin (Urfa), 26.05.1943, TBMM,TBMM ZC (7. Dönem), Cilt:2, s.247.

${ }^{61}$ Kültür Bakanı Saffet Arıkan (Erzincan), 25.05.1938, TBMM,TBMM ZC (5. Dönem), Cilt:25, s.222.

${ }^{62}$ Yavuz Abadan (Eskişehir), 26.05.1943, TBMM,TBMM ZC (7. Dönem), Cilt:2, s.236-237.

${ }^{63}$ Muzaffer Akpınar (Balıkesir), 21.12.1945, TBMM,TBMM TD (7. Dönem), Cilt:20, s.305.

${ }^{64}$ Kemâl Şedele (Diyarbakır), 25.05.1944, TBMM,TBMM ZC (7. Dönem), Cilt:10, s.284.
}

\section{History Studies}


Ankara ve İstanbul'dan başka Doğu Anadolu'da Van'da bir üniversite kurulması konusu uzun yıllar gündemde kalmıştır. 1938 yılında Kültür Bakanı Saffet ARIKAN ${ }^{65}, 1943$ yılında Maarif Vekili Hasan Âli YÜCEL ${ }^{66}, 1950$ yılında da Van milletvekili İbrahim ARVAS, Atatürk'ün Van'da bir üniversite açılmasını emrettiğini ifade etmişlerdir ${ }^{67}$. Ancak Van ve çevresindeki vilâyetlerde liseler olmadığı için üniversiteyi kaldıracak öğrenci potansiyeli bulunmadığı gerekçesiyle bu üniversitenin açılamadığı yine İbrahim ARVAS tarafından dile getirilmiştir $^{68}$.

Ankara'da bir Teknik Üniversite konusu da zaman zaman gündeme gelmiş, fakat gerçekleşmemiştir ${ }^{69}$.Hattâ bir ara bu üniversite inşaatına başlanmış iki binası yapılmış, fakat daha sonra inşaat durdurulmuştur ${ }^{70}$.

Esasen Türk tarihinde üniversite işinin gerektiği seviyede olmadığı hakkında Hamdullah Suphi TANRIÖVER tarafından tarihî bir değerlendirme yapılmıştır ${ }^{71}$ :"Üniversitemizin tarihi çok acıklı bir şeydir. Avrupa memleketlerinin 7-8 asır evvel vücuda getirdikleri üniversiteler var. Biz ilk üniversitemizi Sultan Alparslan ve Melikşah zamanında, yani Selçuklular devrinde Nizamülmülk'ün eliyle tesis ettik. Eğer bu müessesemizi tutabilseydik, bugün Sorbonne'dan bahsedildiği vakit 8 asır evvel, Cambridge ve Oxford'dan bahsedildiği vakit, 7 asır evvel kuruldu derken biz de derdik ki, bizim de 9 asir evvel tesis edilmiş bir üniversitemiz var. Başlarız, devam etmeyiz, tekrar başlarız, tekrar birakırız. Mütemadiyen dura, başlaya, dünyanın bu işte en geri kalmış milletiyiz. Çok hazin bir şey. Anadolu Selçukluları zamanında da bizde aynı tecrübeler yapılmıştır. Bunlar da devam etmedi. Kanunî Sultan Süleyman zamanında Süleymaniye Camiinin etrafinda doğrudan doğruya Cite Üniversitaire denmeye lâylk on müesseseyi bir araya toplamakla meydana gelmiş muazzam bir eser vücut buldu, o da devam etmedi. Nihayet Abdülaziz zamaninda tekrar bir tecrübeye girdik. Şeyh Muhittin-i Efganî, İstanbul'da Adliye sarayında açılan yeni üniversitede bir gün nahim bir cümle söyledi. O cümle şudur: Nübüvvet bir marifettir. Ertesi gün bu da kapatıldl. Itttihat ve Terakkî zamanında bir daha açtık, bu devam ediyordu. Nihayet bizim devrimizde o da kapatıldı ve yani bir isimle, yani şimdiki ismiyle bilmem kaçıncı defa daha açıldı. O halde Balkan milletlerine nazaran bile biz, üniversitesi daha dün açılan bir milletiz, çok eski bir millet olmamıza rağmen."

Türkiye'de üniversite hayatının gelişmesi yolunda neler yapılması gerektiği hakkında Kâzım KARABEKİR de görüşlerini şu şekilde açılamıştır ${ }^{72}$ : “,, iki tip üniversite vardır. Birisi bizdeki müesses tip. Yani bir şehrin kendi sanayiine, kendi içtimaiyatına, kendi iktisadiyatına uygun olarak yıllardan beri kurmuş olduğu bir hayatın içine; memleketin tâ ücra köşelerinden saf, o muhite hiç ünsiyet etmemiş, daha becerikli, daha istihsalciliğe yakın olan gençlerini tutup götürüp oturtmak. Meselâ bizim Beyaztt'taki üniversite...

İkinci bir tip üniversite de şöyledir: Birçok müterakkî memleketlerde kurulmuş, kendi kendini yaratmıştır.Tabii oralarda birçok üniversiteler olduğu için, mıntıkalarının ortalarında istihsal kudreti çok, feyizli toprağl ve ormanı bol yerlerde kurulmuş; etrafinda kendi profesörlerinin ve hattâ, birçok emekli diğer meslek adamlarının, doktoru, baytarl, hukukçusu, subayı ve sairesi birçok pozisyonlarla bezenmiş, çocuklar da onların içerisinde sekizer, onar

\footnotetext{
${ }^{65}$ Kültür Bakanı Saffet Arıkan (Erzincan), 26.05.1938, TBMM,TBMM ZC (5. Dönem), Cilt:25, s.222.

${ }^{66}$ Maarif Vekili Hasan Âli Yücel (İzmir), 26.05.1943, TBMM,TBMM ZC (7. Dönem), Cilt:2, s.251.

${ }^{67}$ İbrahim Arvas (Van), 25.05.1949, TBMM,TBMM TD (8. Dönem), Cilt:16, s.660.

${ }^{68}$ Ibrahim Arvas (Van), 13.02.1950, TBMM,TBMM TD (8. Dönem), Cilt:24, s.519.

${ }^{69}$ Emin Soysal (Maraş), 17.02.1950, TBMM,TBMM TD (8. Dönem), Cilt:24, s.807.

${ }^{70}$ Nihat Erdem (Kırşehir), 20.02.1950, TBMM,TBMM TD (8. Dönem), Cilt:24, s.858.

${ }^{71}$ Hamdullah Suphi Tanröver (İçel), 24.12.1945, TBMM,TBMM TD (7. Dönem), Cilt:20, s.330.

${ }^{72}$ General Kâzım Karabekir (İstanbul), 24.05.1943, TBMM,TBMM ZC (7. Dönem), Cilt:2, s.169.
}

\section{History Studies}


aile hayatı geçiriyor. Hattâ bir yurt yapılsa, kendilerini yaratan yurtlarla şehir içerisindeki yurt arasındaki farkı söylemeye lüzum yoktur... Ikkinci tip üniversiteyi kurmadıkça bu dava halledilemez."

\section{i-Yabancı Okullar}

19. ve 20. yüzyıl başlarında had safhaya varan misyonerlik faaliyetleri, İngiltere, Fransa, İtalya, Amerika vb. gibi devletlerin siyasî amaçlarıyla örtüşerek, Osmanlı Devleti'nin yıkılmasında önemli rol oynamıştır. Çok değişik çalışma metotları olan misyonerlik teşkilâtları, sosyal ve kültürel sahalarda faaliyetlerde bulunmuşlardır. Bu doğrultuda Osmanlı ülkesinde özellikle Hristiyan toplulukların bulunduğu bölgelerde okullar, hastahaneler, yetimhaneler, kiliseler, dispanserler açılmıştır. Bu tür sosyal görüntülü faaliyetlerle, Hristiyan tebaanın bulunduğu bölgeler tespit edilmiş, bu dine mensup olanlara imkânlar sunularak kazandırılmaya çalışılmış ve bu suretle yerli hristiyanlar, batılı devletlerin emperyalist emelleri doğrultusunda Osmanlı Devleti’nin siyasî ve kültürel varlığına mugayir olarak ayrılıkçı tarzda yönlendirilerek kullanılmışlardır ${ }^{73}$. 16. yüzyılın sonlarından itibaren Türkiye'ye gelen cemaatler ve bunlar tarafindan açılan Fransa, Amerika Birleşik Devletleri, İtalya, Avusturya, Rus, İran, İsrail ve Bulgar okulları hakkında çok ayrıntılı çalışmalar yapılmışıır ${ }^{74}$.

Cumhuriyet döneminde Türkiye Büyük Millet Meclisi genel kurulunda bu konu da gündeme gelmiştir. 1935 yılında bazı milletvekilleri, Türkiye'deki yabancı okulların varlığını eleştirmişlerdir ${ }^{75}$ : "Bu milletin ileri gitmesini ve her milletin üstün olmasını arzu ediyorum. Binaenaleyh bir şey vardır ki bendenize dokunuyor. Bu kadar senelerden beri niçin çocuklarımızı Robert Kolej'e, niçin Frerler Mektebine gönderiyoruz. Niçin kızlarımızı SainteJeanne Dark'a gönderiyoruz? Bendenizin sayın bakandan ricam şudur ki, çalışsın, bu vaziyet artık memlekette son bulsun. Bizim memleketimizde teşkilât yapılsın ki çocuklarımız yapılacak mekteplere seve seve gitsin ve seve seve okusun ve zenginler de çocuklarını Cambridge'e, Oxford'a göndermesinler, üniversitelerimize göndersinler. Biz memnunuz. Biz çocuklarımızı buraya gönderebiliriz desinler ve hem de beyhude yere Avrupa'ya paramız gitmesin. Bendeniz bunu temenni ediyorum.” Bu taleplere Millî Eğitim Bakanı, aynı oturumda şu şekilde cevap vermiştir ${ }^{76}$ : "Bizim memlekette filhakika birkaç ecnebi mektebi vardır. Listelerini burada arz etmeye lüzum görmüyorum ve bu mekteplere çocuklarını gönderenlere karşı da bir şey diyemem. Mektepler, kanunu mucibince lâzım gelen şartları kabul etmişler ve bir müessese olarak kurulmuşlardır. Biz de o kurumları kabul etmişiz. Talimatnâmeleri yapılmış, biz de onları tasdik etmişiz ve oralarda millî kültürü verebilecek şekiller husule getirmişiz, muallimler koymuşuzdur. Onun için oraya çocuğunu verip vermemesi bizim için düşünülecek bir cihet değildir."

Okullarda yabancı dil eğitimi konusu üzerinde de durulmuş, 1932 yılında, Ankara'da yabancı dilde eğitim veren bir lise açılması düşünülmüş ${ }^{77}$, fakat gerçekleşmemesi üzerine bir yıl sonra Ankara Lisesi'nde bir yabancı dil sınıfı açılması ve buralara yabancı hocalar getirilmesine teşebbüsedilmiştir ${ }^{78}$. Yabancı dil bilmedikleri için bizim liselerimizden mezun olana öğrencilerin Avrupa üniversitelerindeki dersleri takip edemedikleri, bunun için yabancı dil öğrenmeleri gerektiği vurgulanmıştır ${ }^{79}$. Ama buna rağmen 1950 yılına gelindiğinde, bizim

\footnotetext{
${ }^{73}$ Adnan Şişman,XX. Yüzyıl Başlarında Osmanlı Devleti'nde Yabancı Devletlerin Kültürel ve Sosyal Müesseseleri, Atatürk Araştırma Merkezi Yayını, Ankara, 2006, s. 359.

74 İlknur Polat Haydaroğlu, a.g.e., s. 101-194.

${ }^{75}$ Berç Türker (Afyonkarahisar), 25.05.1935, TBMM,TBMM ZC (5. Dönem), Cilt:3, s.255.

${ }^{76}$ Maarif Bakanı Abidin Özmen (Aydın), 25.05.1935, TBMM,TBMM ZC (5. Dönem), Cilt:3, s.260.

${ }^{77}$ Maarif Vekili Esat Bey (Bursa), 25.06.1932, TBMM,TBMM ZC (4. Dönem), Cilt:9, s.327.

${ }^{78}$ Maarif Vekili Reşit Galip Bey (Aydın), 17.05.1933, TBMM,TBMM ZC (4. Dönem), Cilt:15, s.147.

${ }^{79}$ Sami Erkman (Tunceli), 25.05.1939, TBMM,TBMM ZC (6. Dönem), Cilt:2, s.248.
} 
okullarımızda yeterli ölçüde yabancı dil öğretilemediği için, yabancı okullarından mezun olan gençlerin Türk okullarından mezun olanların önüne geçtiği ve tercih edildiği hususu dikkat çekmektedir $^{80}$. Amerika Birleşik Devletleri ile imzalanan Fulbright Mukavelesi çerçevesinde, ücretleri Türkiye tarafından ödenmek üzere liselerimizde yabancı dil öğretecek öğretmenler, mütehassıslar ve profesörler görevlendirilmesi hükme bağlanmıştır ${ }^{81}$. Bu mukavele Türkiye Büyük Millet Meclisi tarafından kabul edilmiş ve 18 Mart 1950 tarihli Resmî Gazete'de yayınlanarak yürürlüğe girmiştir ${ }^{82}$.

Türkiye'de eğitim imkânı olmayan mühendislik braşlarında yurt dışına öğrenci gönderilmek suretiyle bu alandaki açık kapatılmaya çalışılmıştır. Mühendislik tahsil etmek üzere gönderilen öğrencilere ayda ödenen para miktarı şu şekildedir: Amerika Birleşik Devletleri 98 dolar, İngiltere 98 dolar, İsveç 98 dolar, İsviçre 63 dolar, Almanya 60 dolar, Avusturya 54 dolar, Macaristan 54 dolar, Çekoslovakya 45 dolar, Fransa 50 dolar, Belçika 45 dolar aylık ödeme yapılmıştır ${ }^{83}$.

\section{3-Eğitim Personeli}

\section{a-Öğretmen}

$\mathrm{Bu}$ dönemde eğitim hizmetleri öğretmen, vekil öğretmen, köy öğretmeni, köy eğitmeni kadrolarındaki personel tarafından verilmiştir. Cumhuriyet döneminde öğretmen yetiştirme politikaları, ilkokul, ortaokul ve meslek dersi öğretmenlerinin yetiştirilmesi ile bunun için açılan okullar ve bu okulların öğrenci kaynakları hakkında uzmanlar tarafından ayrıntılı çalışmalar yapılmıştır ${ }^{84}$. Akademik anlamda yapılan bu çalışmaların dışında, eğitici kadrolarının günlük hayatta karşılaş̧ıkları olaylar hakkında Türkiye Büyük Millet Meclisi kürsüsüne yansıyan bilgileri paylaşarak konuya katkı yapmaya çalışacağız.

Cumhuriyet döneminde normal eğitim hizmetlerinin yürütülmesinde ortaya çıkan problemlere ilâve olarak özellikle harf inkılâbından sonra yetişmiş eleman bulmak konusunda daha fazla sıkıntılar yaşanmıştır. Mevcut öğretmen kadrosunun yetersizliği karşısında emekli öğretmenlerden isteyenlerin yeniden hizmete alınması düşünülen ilk tedbir olmuştur ${ }^{85}$. Buna rağmen aradan y1llar geçtikten sonra eğitimde okul ve öğretmen yetersizliği 1srarla dile getirilmiş ${ }^{86}$; hattâ 1937 y1lında 40.000 köyden 35.000 'inde okul ${ }^{87}, 1946$ y1lında 40.000 köyden 32.000'inde öğretmen olmadığı, Millî Eğitim Bakanı tarafından ifade edilmiştir ${ }^{88} .1934$ yılında özellikle orta öğretimde, öğretmen azlığı yüzünden 306 vekil öğretmen görevlendirilmiştir ${ }^{89}$.

Öğretmenlerin problemlerine de dikkat çekilmiştir. 1934 yılında öğretmenlerin hükümetten istekleri şu şekilde dile getirilmiştir ${ }^{90}$ :

1- Maaşlarının diğer devlet memurları gibi muntazaman verilmesi,

2-Mesken bedeli kesintilerinden alacaklarının ödenmesi,

\footnotetext{
${ }^{80}$ Eminittin Çeliköz (Balıkesir), 18.02.1950, TBMM,TBMM TD (8. Dönem), Cilt:24, s.839.

${ }^{81}$ Millî Eğitim Bakanı Tahsin Banguoğlu (Bingöl), 20.02.1950, TBMM,TBMM TD (8. Dönem), Cilt:24, s.858.

${ }^{82}$ T.C. Resmî Gazete, 18 Mart 1950, Sayı:7460, s.18116.

${ }^{83}$ Nafia Vekili Hilmi Bey (Adana), 18.05.1933, TBMM,TBMM ZC (4. Dönem), Cilt:15, s.158.

${ }^{84}$ Yahya Akyüz, a.g.e., s.329-336.

${ }^{85}$ Maarif Vekili Hikmet Bey (Manisa), 29.05.1934, TBMM,TBMM ZC (4. Dönem), Cilt:22, s.443.

${ }^{86}$ Berç Türker (Afyonkarahisar),25.05.1939, TBMM,TBMM ZC (6. Dönem), Cilt:2, s.253.

${ }^{87}$ Naşit Uluğ (Kütahya), 26.05.1937, TBMM,TBMM ZC (5. Dönem), Cilt:18, S.246.

${ }^{88}$ Millî Eğitim Bakanı Reşat Şemsettin Sirer (Sivas), 24.12.1946, TBMM,TBMM TD (8. Dönem), Cilt:3, s.460.

${ }^{89}$ Maarif Vekili Hikmet Bey (Manisa), 29.05.1934, TBMM,TBMM ZC (4. Dönem), Cilt:22, s.443.

${ }^{90}$ Süleyman Fikri Bey (Mersin), 29.05.1934, TBMM,TBMM ZC (4. Dönem), Cilt:22, s.438.
} 
3- Terfilerinin belirli bir şekle konulması ve müfettişlerin ellerine terk edilmemeleri,

4-Tatillerde araştırma gezileri yaparak bilgilerini artırmak için, demiryolları ve vapurlardan yarı fiyatla seyahat edebilmeleri imkânının verilmesi,

5-Okuyacakları meslekî kitapların ucuz bir şekilde bulabilmelerinin temini.

$\mathrm{Bu}$ taleplerden birincisi, ancak 2 Şubat 1948 tarihinde Resmî Gazetede yayınlanan ve yukarda belirtilen 5166 sayılı Özel idarelerden aylık alan ilkokul öğretmenlerinin kadrolarının Millı̂ Eğitim Bakanlığı teşkilâtına alınması hakkında kanun ile mümkün olmuştur. Öğretmenleri ev sahibi yapmak için, maaşlarından yapılan kesintilerle kurulan "ilköğretim Yardım ve Yapı Sandıkları" istenilen sonucu verememiş, burada toplanan paralar amacina uygun olan yerlere sarf edilmemiştir ${ }^{91}$. Terfîlerini de düzenli hale getirecek olan öğretmenliğin bir meslek haline getirilmesi 1944 yıllarında gündeme gelmiştir ${ }^{92}$. Maddî durumlarının düzeltilmesi talepleri uzun yıllar devam etmiş, 1943 yılında 15-20 sene hizmeti olan bir öğretmenin maaşı 20 lira olmuştur ${ }^{93}$. Cumhuriyet'in ilk yıllarında çıkartılan 13 Mart 1924 tarih ve 439 sayılı Orta Tedrisat Muallimleri Kanunu'nun 14. maddesi ile Artvin, Ardahan, Erzurum, Ergani, Bayezit, Bitlis, Hakkâri, Süleymaniye, Kars, Kerkük, Genç, Musul, Van, Dersim, Erzincan gibi doğu vilâyetlerinde görev yapan Ortaokul öğretmenlerine maaş ve fevkalâde ödeneklerinin yarısı kadar daha zam yapılmıştır ${ }^{94}$.

Bundan başka yüksek tahsilini yapıp ilkokul öğretmenliğinden ortaokul öğretmenliğine geçenlerin, ilkokul öğretmenliğindeki hizmetleri dikkate alınmayıp, yeni mezun olmuş bir öğretmen gibi düşük maaşla çalıştırıldıkları şikâyet konusu olmuştur ${ }^{95}$. Öğretmen tayin ve nakillerinin uygun olmayan zamanlarda yapıldığına dikkat çekilerek uzun yıllar bir şehirde çalışan ve oraya alışarak dost çevresi oluşturan öğretmenleri buralardan ayırmak yerine genç öğretmenlerin tayin edilmeleri istenmiştir ${ }^{96}$. İkinci Dünya Harbi dolayısıyla maaşlarının yetersiz kalması dolayısıyla geçim sıkıntısına düşen, kırıcı ve usandırıcı muamelelerden sıkılan, ideolojik bakımdan sisteme intibak edemeyen ve Köy Enstitüsü mezunu genç öğretmenlerin kendi önlerine geçmeleri dolayısıyla bundan huzursuz olan öğretmenler de meslekten ayrılmışlardır. 1946 yılına kadar bu şekilde meslekten ayrılan ilkokul öğretmeni, müfettiş ve maarif müdürü sayıs1 8.000'e yaklaşmıştır ${ }^{97}$.

Diğer taraftan, öğretmenleri psikolojik olarak motive edecek sözler de söylenmiştir. Öğretmenlerin her türlü mahrumiyete rağmen gerçekten bir "misyoner" gibi çalışıp çocukları iyi yetiştirdikleri ${ }^{98}$, öğretmenlerin yeni rejimin müdafileri oldukları ${ }^{99}$, inkılâbın omuzlarına yüklemiş olduğu vazifeyi başardıklar1 ${ }^{100}$, Türk öğretmeninin inkılâbın hakiki bir mürşidi olduğu gibi ifadelere de rastlanmaktadır ${ }^{101}$.

\footnotetext{
${ }^{91}$ Faruk Nafiz Çamlıbel (İstanbul), 29.12.1947, TBMM,TBMM TD (8. Dönem), Cilt:8, s.579.

${ }^{92}$ Cemil Bilsel (Samsun), 25.05.1944, TBMM,TBMM ZC (7. Dönem), Cilt:10, s.271-272.

${ }^{93}$ Hasan Ücöz (Tunceli), 26.05.1943, TBMM,TBMM ZC (7. Dönem), Cilt:2, s.245.

${ }^{94}$ 13.03.1924, ТВMM,TBMM ZC (2. Dönem), Cilt:7, s.386-407.

${ }^{95}$ Nurettin Ünen (Çanakkale),23.12.1946, TBMM,TBMM TD (8. Dönem), Cilt:3, s.399.

${ }^{96}$ Tezer Taşkıran (Kars), 17.02.1950, TBMM,TBMM TD (8. Dönem), Cilt:24, s.813.

${ }^{97}$ Emin Soysal (Maraş), 24.12.1946, TBMM,TBMM TD (8. Dönem), Cilt:3, s.455.

${ }^{98}$ Kılıçoğlu Hakkı Bey (Muș), 29.05.1934, TBMM,TBMM ZC (4. Dönem), Cilt:22, s.439.

${ }^{99}$ Maarif Vekili Hikmet Bey (Manisa), 29.05.1934, TBMM,TBMM ZC (4. Dönem), Cilt:22, s.442.

${ }^{100}$ Hasene Ilgaz (Hatay), 25.05.1944, TBMM,TBMM ZC (7. Dönem), Cilt:10, s.266.

${ }^{101}$ Hikmet Turan Dağlığlu (Antalya), 25.05.1944, TBMM,TBMM ZC (7. Dönem), Cilt:10, s.278.
} 
1950 yılı itibarı ile Millı̂ Eğitim Bakanlığı emrinde 47.600 öğretmenin çalışmakta olduğu; ayrıca 7.400 kadar da memur ve müstahdem bulunduğu, böylece toplam 55.000 kişilik bir personel kadrosu bulunduğu ifade edilmiştir ${ }^{102}$.

\section{b-Köy Öğretmeni}

22 Mart 1926 tarih ve 789 sayılı Maarif Teşkilâtına dair kanun'un yedinci maddesine göre, orta öğretim kurumları arasında Köy Muallim Mektepleri yer almıştır ${ }^{103}$. Bu okullardan beklenen fayda elde edilemediği için dört yıl sonra kapatılmıştır ${ }^{104}$.

Köy öğretmenlerinin yaşadıkları sıkıntılar da şu şekilde dile getirilmiştir ${ }^{105}$ : "Kız olsun, erkek olsun mektepten çıkar çıkmaz köylere gönderilmektedir. Köy hayatını hiç bilmeyen, okutacă̆ l köy çocuklarının ruhiyatını hiç anlamayan bu muallimler, gittikleri köy muhitine ve aralarında çalışacakları köylü ve köy çocuklarını anlamadan, nihayet kasaba, şehirde tek sinıflı bir mektepte çalışmadan ve onu idare etmeden, üç sinıfı bir arada olan köy mekteplerini idare etmek mecburiyetinde kaldiklarından muvaffak olamiyorlar. Gittikleri yerde oturacak yer bulamıyorlar, yemeklerini kendileri pişirmek zorunda kalıyorlar. Bundan dolayıdır ki, istenilen derecede faydalı olamiyorlar."

Köy öğretmenlerinin 1932-1942 yılları arasında makam ücretlerinin ödenmemiş, bunun için 4357 sayılı kanun çıkartılarak bu iş için 96.000 lira ödenek konulmuştur ${ }^{106}$. Buna rağmen bazı vilâyetlerde makam tazminatı yine ödenememiş, bu konudaki sıkıntıların devam etmesi üzerine 1949 yılında bu fasıla Maliye Bakanlığı tarafından 2 milyon lira tahsis edilmiştir ${ }^{107}$.

Köylerde çalışan öğretmenlerin orta okul ve lise çağına gelmiş çocuklarının şehirlere gidip eğitim almaları konusunda da sıkıntılar yaşanmıştır ${ }^{108}$. Bununla birlikte bir şekilde okumak için şehre giden çocukların bir daha köylerine dönmek istemedikleri de bilinmektedir ${ }^{109}$ : “...ortaokula devam etmek için şehir ve kasabalara gidiyorlar. Bu çocuklar burada çok sefalet çekiyorlar, yetişemiyorlar. Pek azı hayatlarını kurtarlyorlar. Bunlar orta tahsili tamamlayıp da liseye gitmek istedikleri zaman yine, lise bulunan muhite gidiyorlar, birçok güçlükle karşılaşıyorlar. Çoğu hayatını kazanamıyor. Orta tahsilini tamamlayanlar ise artık köylerine dönmedikleri için, bunlar köy için kayıp edilmiş birer klymet haline geliyorlar. Aynı zamanda kasaba ve şehirlere de mal olamıyorlar." Böylece köye göre öğretmen yetiştirme hareketinin ilk denemesine girişilerek, 1927'de Mustafa Necati'nin bakanlığı döneminde Denizli Erkek Muallim Mektebi, Köy Muallim Mektebi'ne çevrilmiş ve Kayseri'de Zincirdere köyünde öğretim süreleri üç yıl olan bir Köy Muallim Mektebi açılmıştır.

\section{c-Köy Ĕgitmeni}

Nüfusları öğretmen gönderilmesine elverişli olmayan köylerin öğretim ve eğitim işlerini görmek, ziraat işlerinin fennî bir şekilde yapılması için köylülere rehberlik etmek üzere köy

\footnotetext{
${ }^{102}$ Millî Eğitim Bakanı Tahsin Banguoglu (Bingöl), 20.02.1950, TBMM, TBMM TD (8. Dönem), Cilt:24, s.848.

${ }^{103}$ Resmî Cerîde, 3 Nisan 1926, Say1:338, s.1233.

${ }^{104}$ Aydoğan Ataünal,Türkiye'de İlkokul Öğretmeni Yetiştirme Sorunu (1923-1994), Millî Eğitim Bakanlığ1 Yayını, Ankara, 1994, s.16.

${ }^{105}$ Hasib Ahmet Aytuna (Tokat), 25.07.1939, TBMM,TBMM ZC (6. Dönem), Cilt:2, s.260.

${ }^{106}$ Salih İnankur (İçel), 29.12.1947, TBMM,TBMM TD (8. Dönem), Cilt:8, s.604.

${ }^{107}$ Salih İnankur (İçel),25.02.1949, TBMM,TBMM TD (8. Dönem), Cilt:16, s.659.

${ }^{108}$ Hüseyin Ulusoy (Niğde), 29.12.1947, TBMM,TBMM TD (8. Dönem), Cilt:8, s.601.

${ }^{109}$ Mustafa Reşit Tarakçıŏlu (Trabzon), 29.12.1947, TBMM,TBMM TD (8. Dönem), Cilt:8, s.593.
}

\section{History Studies}


eğitmenleri istihdamını öngören 3238 sayı ve 11 Haziran 1937 tarihli Köy Eğitmenleri Kanunu, 24 Haziran 1937 tarihinde Resmî Gazetede yayınlanarak yürürlüğe girmiştir ${ }^{110}$.

Bu kanuna bağlı olarak nüfusu 150'den az olan köylerde eğitim hizmeti vermek amaciyla köy eğitmen kursları açılmıştır. Askerliğini yapmış, okuma yazma bilen, yaşantısını köylerde geçirecek, uygun kişiler bulunup köy eğitmen kurslarında çok yönlü bir eğitimden geçirildikten sonra, köylere gönderilmişlerdir. Köy Enstitülerinin kurulmasıyla beraber köy eğitmen kursları, o bölgedeki Köy Enstitülerine bağlanarak faaliyet göstermişlerdir. Köy çocuklarına dört işlemin, okuma-yazmanın yanında yoğun bir biçimde tarım ve hayvancılık, tavukçuluk, sebzecilik, meyvecilik gibi işler, köy eğitmenleri tarafından fennî bir şekilde öğretilmeye çalışılmıştır.15 Nisan 1947 tarihinde açılan 12. dönem Eğitmen Kursu, köylere eğitmen yetiştirmek için açılmış olan eğitmen kurslarının sonuncusu olmuştur. Bu tarihten sonra, bir daha eğitmen kursu açılmamıştır ${ }^{111}$. 1937'de 79 kişi ile başlayan Köy Eğitmenlerinin sayısı sekiz bine kadar ulaşmıştır. Bazı eğitmenlerin görevden ayrılmasından sonra 1950 yılında toplam Eğitmen sayıs1 6500'e düşmüştür ${ }^{12}$. Köy Eğitmenliği lağvedildikten sonra kalan 2200 eğitmen, ancak 12 Eylül 1963 tarihinde Millı̂ Eğitim Bakanlığı öğretmen kadrolarına geçirilmişlerdir $^{113}$.

Köy Eğitmenliği uygulamasının günlük hayata yansımaları şu şekilde tespit edilmiştir ${ }^{114}$ : “... muallimsiz köy mektepleri için muallim yetiştirmek üzere Maarif Vekâleti’nin üç seneden beri tatbik ettiği ĕgitmen teşkilâtından bahsetmek istiyorum. Ziraat Vekâleti ile elbirliği yaparak, memleketin muhtelif mıntıkalarında, köydeki mektepler için muallim yetiş̧irmek üzere açılan kurslardaki zirâ̂ malûmat da gayet amelî bir surette tedris edildiğinden dolayı köylere giden bu eğitmenler yalnı çocukları okutmakla değil, aynı zamanda köylüleri amelî ziraat nokta-i nazarından da tenvir etmeleri itibariyle köy kalkınmasina, yani yeni ziraatin köylerde yerleşmesine çok hizmet etmiş oluyorlar. $\ddot{U C ̧}_{c}$ seneden beri tatbik edilen bu sistemle şimdiye kadar dört bin eğitmen yetiştirilmiştir. Maarif Vekâleti'nden edindiğimiz malûmata göre memleketin daha 28 bin ĕgitmene ihtiyacı vardır. Muallimsiz köylerin eğitmen ihtiyacı ancak 14 senede ikmâl edilebilecektir." 1950 y1lı itibarıla 6000 köy eğitmeni bulunduğu, maaşlarının 30 lira olduğu ve geçim sıkıntısı içerisinde oldukları ifade edilmiştir ${ }^{115}$.

Köy Eğitmenlerinin bir sıkıntısı da bu projeyi Millî Eğitim Bakanlığı ile birlikte yürüten Tarım Bakanlığı'nın taahhütlerini yerine getirmemesinden kaynaklanmaktadır. Zira Köy eğitmenlerinin kullanacağı ziraat aletleri, Tarım Bakanlığı tarafından temin edilip eğitmenlere verilecek olmasına rağmen Tarım Bakanlığının bu aletleri temin etmemesi üzerine alet sıkıntısı çekmişlerdir ${ }^{116}$.

\section{d-Denetmenler (Müfettişler)}

Yüksek Köy Enstitüsünden mezun olmuş olan öğretmenler denetmen unvanını almışlardır. Bunlara Gezici Başöğretmende denilmiştir. Bunlar aslında müfettişlik işlerini yapmaktadırlar,

\footnotetext{
${ }^{110}$ T.C. Resmî Gazete, 24 Haziran 1937, Sayı:3629, s.8367.

${ }^{111}$ Çiğdem Erdem, “'Cumhuriyet Yönetiminin 1930’lu Y1llarda Köyde ve Köylülükte Dönüşümü Gerçekleştirme İsteğinin Bir Aracı Olarak Köy Eğitmen Kursları”, Gazi Üniversitesi İktisadî ve İdarî Bilimler Fakültesi Dergisi, Cilt:10, Say1, s, 2008, s.187-200.

${ }^{112}$ Millî Eğitim Bakanı Tahsin Banguoğlu (Bingöl), 20.02.1950, TBMM,TBMM TD (8. Dönem), Cilt:24, s.849.

${ }^{113}$ Şinasi Sönmez, “Köy Eğitmenleri ve Kadro Sorunları”, Karaelmas Journal of EducationalSciences Cilt:1, Sayı:1, 2013, s.59.

${ }^{114}$ Ahmet Hamdi Dikmen (Konya), 25.05.1939, TBMM,TBMM ZC (6. Dönem), Cilt:2, s.254.

${ }^{115}$ Hıfzı Oğuz Bekata (Ankara), 17.02.1950, TBMM,TBMM TD (8. Dönem), Cilt:24, s.804.

${ }^{116}$ Yavuz Abadan (Eskişehir), 27.12.1945, TBMM,TBMM TD (7. Dönem), Cilt:20, s.521.
}

\section{History Studies}


fakat bunlara müfettiş değil de denetmen denildiği için müfettişlerin sahip oldukları özlük haklarına sahip olamamak gibi sıkıntıları olmuştur ${ }^{117}$.

\section{e-Maarif Eminliği}

789 sayı 22 Mart 1926 tarihli Maarif Teșkilâtına dair kanun 3 Nisan 1926 tarihinde yayınlanarak yürürlüğe girmiştir ${ }^{118}$. Bu kanunun ilgili maddesine göre ülke 13 bölgeye ayrılarak buralara birer Maarif Emini atanmış ve bu sayede bakanlık hizmetlerinin daha etkili bir şekilde yürütülmesine çalışılmıştır ${ }^{119}$. Bu konu, Millî Eğitim Bakanı Mustafa Necati Bey tarafından Türkiye Büyük Millet Meclisi genel kurulunda da dile getirilmiştir ${ }^{120}$.

Bu kanunun 27. maddesine göre Maarif Emini, ilkokul öğretmen ve yardımcılarını, okul müdürlerini, ilköğretim müfettişlerini, Eminlik Hey’etindeki görevlileri, kendi bölgesindeki vilâyetlerin eğitim bürolarını, başkâtip ve kâtiplerini bakanlık adına tayin ve görevden alma; vilâyetlerin eğitim bütçelerinin hazırlanması hakkında tekliflerde yetkilerine sahiptir.

\section{4- Halkevleri}

Halkevleri, halkı pozitivist dünya görüşü doğrultusunda eğitmek, yeni rejimi destekleyecek yeni bir siyasi kültür oluşturmak, halkın kaynaşarak birbirini anlayan ve fikir alışverişinde bulunan insanlar haline gelmesini sağlamak, gençleri zararlı alışkanlardan uzak tutmak, sağlıklı nesiller yetiştirmek, halkı modern bir zihniyete kavuşturmak, köy ile kent arasındaki farkı ortadan kaldırmak ve hem köylerde hem de kentlerde yetişkin eğitimini gerçekleştirmek, cehaleti yok etmek, milliyetçi, laik ve halkçı fikirleri aşılamak gibi nedenlerle açılmışıır ${ }^{121}$.

Yapılan hazırlıklar sonucunda ilk Halkevleri 19 Şubat 1932 tarihinde 14 merkezde

Volume 11

Issue 2

A tribute to

Prof. Dr.

Mehmet Ali

ÜNAL

April

2019 açılmıştır. Bu merkezler Afyon, Ankara, Aydın, Bolu, Bursa, Çanakkale, Denizli, Diyarbakır, Eminönü, Eskişehir, İzmir, Konya, Malatya ve Samsun'du. Aslında bunlar açılışa kadar hazırlıkları tamamlanabilen Halkevleri idiler. Antalya, Bilecik, Edirne, Gaziantep, Giresun, Silifke, Kastamonu, Kayseri, Kırklareli, Kocaeli, Kütahya, Ordu, Rize, Sinop, Şebinkarahisar, Tekirdağ, Trabzon, Van, Yozgat ve Zonguldak'taki Halkevleri ise 19 Şubat tarihine yetişemeyip 24 Haziran 1932 tarihinde açılmışlardır. Eklenen bu 20 yeni ev ile birlikte Halkevlerinin sayısı 1932 Haziranı itibariyle 34'e yükselmiştir ${ }^{122}$. 1947 yılı itibariyle, toplam 463 Halkevi ve 4110 Halkodası açılmıştır ${ }^{123}$.

Halkevlerinin açılış gerekçeleri, İçişleri Bakanı Şükrü Kaya Bey tarafından da şu sözlerle ideal vatandaş yetiştirmek olarak açıklanmıştır ${ }^{124}$ :"Bizim aradiğımız vatandaş, memleketin menfaatini milletin mukadderatını tıpkı o memleketin başında bulunmuş en büyük mes'ûl gibi düşünerek, çalışarak bilen, bildiğini her yerde, her zaman söyleyerek memleketle alâkadar olan vatandaştır. " Halkevlerinin fonksiyonlarının ise, ülkemizin büyük halk kitlesinin tenvir ve irşat faaliyetlerine konferanslar, törenler yaparak katkı sağlamak olduğu ifade edilmiştir ${ }^{125}$. Halkevleri, bu çalışmalar sırasında daima yükselmek ve ilerlemek hissini taşıyan Türk

\footnotetext{
${ }^{117} \mathrm{H}$ ıfzı Oğuz Bekata (Ankara), 17.02.1950, TBMM,TBMM TD (8. Dönem), Cilt:24, s.804.

${ }^{118}$ Resmî Cerîde, 30Nisan 1926, Say1:338, s.1233.

${ }^{119}$ Mustafa Eski, "Mustafa Necati”, Atatürk Araştırma Merkezi Dergisi, Temmuz 1996, Cilt: XII, Sayı: 35, s.476.

${ }^{120}$ Maarif Vekili Mustafa Necati Bey (İzmir),12.04.1927, TBMM,TBMM ZC (2. Dönem), Cilt:31, s.86.

${ }^{121}$ Yavuz Özdemir-Elif Aktaş, "Halkevleri (1932'den 1951'e)", A.Ü.Türkiyat Araştırmaları Enstitüsü Dergisi [TAED] 45, Erzurum, 2011, s.243.

${ }^{122}$ Yavuz Özdemir-Elif Aktaş,a.g. makale,s.247.

${ }^{123}$ Muhsin Adil Binal (Konya), 28.12.1947, TBMM,TBMM TD (8. Dönem), Cilt:8, s.558-559.

${ }^{124}$ Dahiliye Vekili Şükrü Kaya Bey (Muğla), 26.06.1932, TBMM,TBMM ZC (4. Dönem), Cilt:9, s.247.

${ }^{125}$ Dahiliye Vekili Şükrü Kaya Bey (Muğla), 25.05.1937, TBMM,TBMM ZC (5. Dönem), Cilt:18, s.221.
} 
gençlerine, Atatürk'ün kurduğu cumhuriyet rejiminin kudsiyetini ve yükseltici prensiplerini telkin etmiştir ${ }^{126}$.

Halkevlerinin "1932'de Atatürk ve onun Cumhuriyet Halk Partisi tarafindan kurulan yetişkin eğitimi cemiyeti ve kültürel merkez idiler. Onlar, ülkenin her yerinde şehirlerde, kasabalarda ve hatta küçük köylerde bile yerleşen, hükümet himayeli ve destekli merkez"şeklindeki tarifleri ${ }^{127}$, bu kurumların gerek zamanında gerekse günümüze kadar çeşitli tartışmalara sebep olmuştur. Bütçeden Halkevlerinin finansmanı için ayrılan ödeneğin Cumhuriyet Halk Partisi hesabına yatırılmış olması eleştirilmiştir ${ }^{128}$. Halkevlerinin bugünkü şeklini değiştirip, siyasî mülâhazalardan sıyrılarak, gömleğini değiştirerek partili partisiz her vatandaşa kapılarını açar ve umumî bir müessese haline gelirse, o zaman bütçeden yardım yapılmasının mümkün olacağı ifade edilmiştii ${ }^{129}$.

Halkevlerinin 1931 yılında kendini fesheden Türk Ocaklarının yerine kurularak, onların mal varlıklarının bu kuruma devredilmesi, eski Türk Ocağı yetkilileri tarafından eleştirilmiştir ${ }^{130}$. Buna karşılık Halkevlerinin Inkılâp Terbiyesi" verdiğ $i^{131}$ ve bir Halk Üniversitesi olduğu cevapları verilmiştir ${ }^{132}$.

Halkevleri, 8 Ağustos 1951 tarihinde 5830 sayılı kanun ile kapatılmıştır. Kanun, 11 Ağustos 1951 tarihli Resmî Gazetede yayınlanarak yürürlüğe girmiştir ${ }^{133}$.

\section{5-Din Eğitimi}

\section{a-Köy Hocaları}

1935 yılında, köylerde vatandaşlara din hizmeti verecek eleman ihtiyacını karşılamak üzere, Köy Hocası sıfatını taşıyan kişilerin yetiştirilerek bu alandaki açığın kapatılması teklif edilmiştir ${ }^{134}$. Bu teklif uygulamaya konulmuş, ancak yıllar sonra bunların yetersizliği anlaşılarak, meslekî bir kurstan geçirilmeleri istenmiştir" ${ }^{135}$ : "Birçok köylerde hocalar vardır. Bu hocalar köylünün aralarında topladı̆̆ı buğdaylar karşıllğında çalışırlar. Bunlar nasıl çalışırlarsa çalışsınlar, ne olursa olsun bir maaş verelim, vermeyelim, fakat bunların kafalarını aydınlatmak şarttır, bugünkü gidişe göre. Şimdi Diyanet İşleri Riyaseti, yaz mevsimlerinde tayin edeceği bir müddet için, ben bunun iki buçuk aydan aşağı olmamasını istiyorum, bir kurs açsınlar, bu kurslarda dinlerine taallûk eden işlerin de aydınlatılacağl gibi, dünün hallerinden, dünya hallerinden, gidiş ve gelişten, iktisadiyattan, onlarl uyandırmak ve sonra da biraz ăgızlarını düzeltmek, yani okuyuşlarını kıraatlendirmek şarttır."

Bazı milletvekilleri, bunu da yeterli görmeyerek ilkokulu bitirmiş köylü çocuklarından seçileceklerin Köy Imam Hatip Kursu denilen bir kurstan geçirilerek köylere kadrolu imam olarak atanmaları gerektiğini tavsiye etmiştir ${ }^{136}$.

Daha sonra, sadece köyleri değil, şehirleri de ilgilendiren gelişmeler meydana gelmiştir. Millî Eğitim Bakanlığı, okullarda din dersleri okutmaya başlamıştır ${ }^{137}$. İlkokullardaki din dersi

\footnotetext{
${ }^{126}$ Berç Türker (Afyonkarahisar); 24.05.1938, TBMM,TBMM ZC (5. Dönem), Cilt:25, s.153.

${ }^{127}$ Yavuz Özdemir-Elif Aktaş; a.g.makale, s.248.

${ }^{128}$ Adnan Menderes (Kütahya), 26.12.1947, TBMM,TBMM TD (8. Dönem), Cilt:8, s.297.

${ }^{129}$ Hasan Dinçer (Afyonkarahisar), 28.12.1947, TBMM,TBMM TD (8. Dönem), Cilt:8, s.558.

${ }^{130}$ Hamdullah Suphi Tanrı̈över (İstanbul), 25.02.1949, TBMM,TBMM TD (8. Dönem), Cilt:16, s.617.

${ }^{131}$ Cevat Dursunoğlu (Erzurum), 17.02.1950, TBMM,TBMM TD (8. Dönem), Cilt:24, s.762.

${ }^{132}$ Hulûsi Oral (Denizli),17.02.1950, TBMM,TBMM TD (8. Dönem), Cilt:24, s.764.

${ }^{133}$ Yavuz Özdemir-Elif Aktaş,a.g. makale, s.260.

${ }^{134}$ Mithat Aydın (Trabzon), 25.05.1935, TBMM,TBMM ZC (5. Dönem), Cilt:3, s.256.

${ }^{135}$ Eminittin Celiköz (Balıkesir), 23.02.1949, TBMM,TBMM TD (8. Dönem), Cilt:16, s.449.

${ }^{136}$ Ibrahim Arvas (Van),25.02.1949, TBMM,TBMM TD (8. Dönem), Cilt:16, s.661.
} 
müfredatının yetersiz bulunması üzerine ${ }^{138}$, Diyanet İşleri Başkanlığı'nda kurulan bir komisyon tarafından yeni bir müfredat programı hazırlanarak Millî Eğitim Bakanlığı Talim ve Terbiye Hey'etince de onaylandıktan sonra yürürlüğe konmuştur ${ }^{139}$.

İlâve olarak Diyanet İşleri Başkanlığı tarafından Kur'ân-ı Kerîm Okulları açılmış ve buralarda, gelen öğrencilere, yetkili öğreticiler tarafından kur'anın talimi, tecvidi ve din dersleri verilmiştir. Öğreticiler günün belirli saatlerinde değil, sabah 09.00'dan 16.00'a kadar görev yapmışlardır ${ }^{140}$.

Bütün bunlara rağmen Ramazan ayı geldiği zaman köylerde Ramazan Hocası denilen kişilerin ortaya çıktığı görülmektedir ki bunların yüzde 70'inin cahil olduğu, bunların halk üzerinde aykırı etkilerinin olduğu tespit edilmiş ve hükümetin bu probleme bir çözüm bulması istenmiştir ${ }^{141}$.

Din eğitimin amacının Türkiye üzerindeki komünizm propagandalarına karşı koymak olduğu görülmektedir. Komünizmin en büyük düşmanının din olduğu ${ }^{142}$ ve Türk milletinin dinine sarılmasıyla bu tehlikeden uzak kalacağı ifade edilmiştir ${ }^{143}$.

\section{b-Cami Görevlileri}

Normal zamanlarda imam ve müezzinlerden başka, cami görevlilerinin salâcılar, buhurdancılar, tesbihçiler ve muvakkitler olduğu bilinmektedir ${ }^{144}$. Ancak son 30 y1lda yeteri kadar din adamı yetişemediği için kadrolar büyük ölçüde boş kalmıştır ${ }^{145} .1946$ yılı itibarı ile mazbut vakıflara bağlı 2115, münhal vakıflara bağlı 392; halk tarafindan idare edilen 2005 olmak üzere toplam 4512 cami ve mescit tespit edilmiştir ${ }^{146}$. Buna karşıllı meselâ Hatay’daki ilçelerdeki camilerin çoğunda imam ve müezzin olmadığ ${ }^{147} ; 60$ ilçedeki müftülük kadrosunun boş olduğu anlaşılmıştır ${ }^{148}$.

Vakıflar idaresindeki camilerin bakımında sıkıntılar yaşanmıştır. Depremlerden ve başka sebeplerden dolayı yıkılan ve tahrip olan camilerin bakım ve onarımlarının yapılamadığ görülmektedir ${ }^{149}$. Toprak Mahsulleri Ofisi'ne depo lâzım olduğu veya başka kurumlara bina lâzım olduğu zaman Vakıflara bağlı cami ve diğer binaların tahsis edildiği ${ }^{150}$; İkinci Dünya Savaşı yıllarında Erzurum'daki bazı camilerin askerî ihtiyaçlar için kullanıldı̆̆ı, savaşın sonunda boşaltıldığ 1 ancak bu camilerdeki tahribatın tamir edilmediği dile getirilmiştir ${ }^{151}$. Hasankale'deki dört camiin masrafının ve hizmetlilerin maaşlarının halk tarafından verildiği hususu da bir eleştiri konusu olmuştur ${ }^{152}$. Bu tür eleştirilere verilen cevapta, vakıfların

\footnotetext{
${ }^{137}$ Sinan Tekelioğlu(Seyhan), 23.02.1949, TBMM,TBMM TD (8. Dönem), Cilt:16, s.447.

${ }^{138}$ İbrahim Arvas (Van), 17.02.1950, TBMM,TBMM TD (8. Dönem), Cilt:24, s.817.

${ }^{139}$ Millî Eğitim Bakanı Tahsin Banguoğlu (Bingöl), 20.02.1950, TBMM,TBMM TD (8. Dönem), Cilt:24, s.857-858.

${ }^{140}$ Eminittin Çeliköz (Balıkesir), 23.02.1949, TBMM,TBMM TD (8. Dönem), Cilt:16, s.448-449.

${ }^{141}$ Orgeneral Fahrettin Altay (Burdur), 14.02.1950, TBMM,TBMM TD (8. Dönem), Cilt:24, s.556.

${ }^{142}$ Sinan Tekelioğlu (Seyhan), 14.02.1950, TBMM,TBMM TD (8. Dönem), Cilt:24, s.555.

${ }^{143}$ Sinan Tekelioğlu (Seyhan), 23.02.1949, TBMM,TBMM TD (8. Dönem), Cilt:16, s.448.

${ }^{144}$ Ahmet Remzi Bey (Gaziantep), 17.04.1927, TBMM,TBMM ZC (2. Dönem), Cilt:31, s.202.

${ }^{145}$ Sinan Tekelioğlu (Seyhan), 23.02.1949, TBMM,TBMM TD (8. Dönem), Cilt:16, s.447.

${ }^{146}$ Sedat Pek (Kocaeli), 30.12.1946, TBMM,TBMM TD (8. Dönem), Cilt:3, s.813.

${ }^{147}$ Orgeneral Eyüp Durukan (Hatay), 25.02.1950, TBMM,TBMM TD (8. Dönem), Cilt:24, s.1285.

${ }^{148}$ General Vehbi Kocagüney (Erzurum), 14.02.1950, TBMM,TBMM TD (8. Dönem), Cilt:24, s.554.

${ }^{149}$ İhsan Yalçın (Bolu), 27.02.1949, TBMM,TBMM TD (8. Dönem), Cilt:16, s.960.

${ }^{150}$ İhsan Yalçın (Bolu), 27.02.1949, TBMM,TBMM TD (8. Dönem), Cilt:16, s.960.

${ }^{151}$ General Vehbi Kocagüney (Erzurum), 25.02.1950, TBMM,TBMM TD (8. Dönem), Cilt:24, s.1280.

${ }^{152}$ General Vehbi Kocagüney (Erzurum), 25.02.1950, TBMM,TBMM TD (8. Dönem), Cilt:24, s.1281.
}

\section{History Studies}


gelirlerinin, kendilerine verilen görevleri yapmaya yetmediği için hizmetlerde aksama olduğu ifade edilmiştir ${ }^{153}$.

Diyanet İşleri Başkanı'nın seçimlerde Cumhuriyet Halk Partisi propagandası yapması ${ }^{154}$, Burdur'da müftülük binasına altı oklu Cumhuriyet Halk Partisi bayrağı asıldığı eleştirilere konu olmuştur ${ }^{155}$.

\section{c-Türkçe Hutbe ve Kur'ân-ı Kerîm'in Tercümesi}

Türkçe hutbe konusunda alınan kararın uygulaması hakkında, 1926 yılında Türkiye Büyük Millet Meclisinde görüşmeler yapılmış, Diyanet İşleri Başkanlığı'nın bu konudaki çalışmaları sorulmuştur ${ }^{156}$. Bu konuda yapılan hazırlıkların sonunda ilk Türkçe hutbe, 5 Şubat 1932 tarihinde Süleymaniye Camiinde okunmuştur ${ }^{157}$.

Kur'ân-1 Kerîm'in Türkçeye tercümesi konusu da aynı oturumda gündeme gelmiş, bu konudaki çalışmaların ne safhada olduğu sorulmuş ve çalışmaların devam ettiği anlaşılmıştır ${ }^{158}$. 1930 yılında, Kur'â1 Kerîm tercümesi için, şimdiye kadar 50.000 lira ödenek ayrıldığ 1 halde henüz bitirilemediğinden şikâyet edilmiştir ${ }^{159} .1934$ yılında 16.000 lira daha tahsis edildiği anlaşılmaktadır ${ }^{160}$. 1949 y1lında bu konu hâlâ gündemdedir ${ }^{161}$ : "Bu memleketin yüzde 95 'i müslümandır. Çok doğru. Bu Müslüman olan halk aynı zamanda Türktür ve dili de Türkçedir. Türk milletine mensuptur. Bütün dünya bir kültür gelişmesi içinde iken mukaddes kitaplarını kendi dilleriyle okurken, bizim büyük Türk milleti Kur'ân-ı Kerîm'i niçin Türkçe olarak okuyamıyor? Kur'ân-ı Kerîmi niçin Türkçeye çevirmiyoruz? Bunun yapılmasını Diyanet Isşleri Reisinden rica ediyoruz."

Kur'ân-1 Kerîm Tercümesi işi, Diyanet İşleri Başkanlığı tarafından, daha önce Kur'ân-1 Kerîm Tefsîri yazmakla görevlendirilen Elmalı' lı Muhammed Hamdi’ye verilmiştir ${ }^{162}$.

\section{6-Güzel Sanatlar Eğitimi}

\section{a-Müzik}

Güzel sanatlar eğitimi konusu, Türkiye Büyük Millet Meclizi Zabit Cerîdesindeki bilgilere dayandırılarak incelenecektir. Ad1 geçen konuşmalarda Türk müziğinin medenî bir müzik olabilmesi için yenilenmesi gerektiği ve bunun nasıl yapılacağı şöyle tarif edilmiştir ${ }^{163}$ : "Türk musikisi senelerden beri Türk kültürünü tamamıyla hazmetmemiş bazı kimseler tarafindan adeta bir ticaret metal haline getirilmiştir. Cumhuriyete lâyık bir musikinin vücut bulmamasına sebep budur... Cumhuriyet musikisini yalnız halk musikisinden çıkaramayacakları muhakkaktır. Elbette Avrupa'yı takip edeceğiz. Fakat onu bilâkaydüşart olarak değil, kendimize uydurarak almamız lâzım."

\footnotetext{
${ }^{153}$ Devlet Bakanı ve Başbakan Yardımcısı Nihat Erim (Kocaeli), 25.02.1950, TBMM,TBMM TD (8.Dönem) Cilt:24, s.1286.

${ }^{154}$ Osman Nuri Köni (İstanbul), 14.02.1950, TBMM,TBMM TD (8. Dönem), Cilt:24, s.554.

${ }^{155}$ Kemâl Zeytinoğlu (Eskişehir), 14.02.1950, TBMM,TBMM TD (8. Dönem), Cilt:24, s.558-559.

${ }^{156}$ Tunalı Hilmi Bey (Zonguldak), 15.05.1926, TBMM,TBMM ZC (2. Dönem), Cilt:25, s.171.

${ }^{157}$ Akşam, 6 Şubat 1932.

${ }^{158}$ Hakkı Tarık Bey (Giresun),16.05.1926, TBMM,TBMM ZC (2. Dönem), Cilt:25, s.171.

${ }^{159}$ K1lıçoğlu Hakkı Bey (Kocaeli), 17.05.1930, TBMM,TBMM ZC (3. Dönem), Cilt:19, s.92.

${ }^{160} 27.05 .1934$, TBMM,TBMM ZC (4. Dönem), Cilt:22, s.331.

${ }^{161}$ Dr. Ahmet Hamit Selgil (Ankara), 23.02.1949, TBMM,TBMM TD (8. Dönem), Cilt:16, s.450.

${ }^{162}$ Hidayet Aydar, "Kur'an”, Türkiye Diyanet Vakfi İslâm Ansiklopedisi, Cilt: 26,Ankara, 2002, s.407.

${ }^{163}$ Dr. Osman Şevki Uludağ (Konya), 26.05.1937, TBMM, TBMM ZC (5. Dönem), Cilt:18, s.250-251.
} 
Halk türkülerine Avrupâ̂ armoniler yapılması hususuna şu sözlerle dikkat çekilmiştir ${ }^{164}$ :"Maarif Vekâleti halk şarkıları topluyor. Bu onun vazifesidir. Folklor dediğimiz sahada, halk şarkılarının toplanmasını iyi bir gözle karşılarız. Meselâ İstanbul'daki konservatuvar klâsik eserler topluyor. Ankara'da da halk şarkıları toplanıyor. Fakat halk şarkılarını toplama masrafi yaninda bir de onlarl armonize etme masrafi konmuş. Armoni melodinin süsüdür. Anadolu'nun bağrından, ruhundan kopup gelen nağmeleri garp usûlü ile armonize etmenin mânâsı var midır yok mudur bilmem."

Türk müziğinin cumhuriyete uymayan tek eserimiz olduğu ${ }^{165}$, radyoda yayınlanan müziğin uzun bir inilti olduğu ${ }^{166}$; hattâ müziğimizin meyhane müziği olduğu şeklindeki eleştirilere karş1, müziğimizin azametli ve zevk verici tarafları olduğu, makamların mahiyetlerinin ayrı ayrı tesirleri olduğu ifade edilmiştir ${ }^{167}$.

Radyoda Türk müziğinin yayınlanmasının halkı teceddüt ve inkılâptan geri bıraktığı ve tamamen kaldırılması gerektiği hakkındaki görüşler eleştirilerek ${ }^{168}$; tam tersi radyoda Türk müziğine ayrılan zamanın az olduğu ve bunun tatmin edici seviyeye getirilmesi gerektiği ifade edilmiştir ${ }^{169}$. Diğer bir milletvekili, bu konudaki görüşlerini, "Her milletin radyo yayınlarında millî musikinin büyük bir payı vardır. Halbuki bizde bu pay asgarî bir hadde biliniyor. Vakıa bu durumun memlekette garp musikisi zevkini yaymak için ihtiyar olunduğu söyleniyor. Fakat fikrime göre böyle bir tedbire gidilmesi, millî musiki yayınının yeter bir hadde tutulmasına mani olmaz." sözleriyle ifade etmiştir ${ }^{170}$.

Radyoda Türk müziği yayını yasağının kaldırılması hakkında Atatürk ile ilgili bir anektot şöyle anlatılmıştı1"171: “... bir sıra Atatürk zamanında alaturka, radyodan kalkmış idi. En nihayet bir gün Tamburacı Osman Pehlivan geldi, bir hava çaldı. Atatürk ağlamaya başladı. Sebebini sordum, niye ağlamayayım ki dedi, anamı hatırladım, bu anamın şarkısını, bizim binbir hatıramı vardır. Alaturkayl kaldıramayı dedi. Annem beni ninni ile büyüttü...Beethoven ile değil. Bunun üzerine tekrar alaturkanın çalınmasına müsaade etti.",

Atatürk'ün bu konudaki görüşlerinin, ink1lâp yapan bir neslin mahrumiyet ve fedakârlıklara katlanması gerektiği; ancak bunun Türk müziğinin radyoda tamamen yasaklanması anlamına gelmediği, batıya yönelik millî ve ileri bir Türk müziğinin oluşturulması şeklinde olduğu, konunun uzmanları tarafindan da tespit edilmiştir ${ }^{172}$.

Millî musikinin, "halk melodileriyle ruhu beslemiş, batı müziği tekniğine kayıtsız şartsız bağll olan ve Türkten başka bir şey olmayan” eserler olacağı dile getirilmiştir ${ }^{173}$. Diğger bir milletvekili de bu konuda, “... Garp tekniğiyle Türk musikisinden istifade edilerek yapılmış bir eseri dinlerseniz kendi vatanımızın kokusunu, kendi vatanımızın sesini, hattâ tarihimizin sesini alırsınız" demiştir ${ }^{174}$.

${ }^{164}$ Dr. Osman Şevki Uludağ (Konya), 25.05.1939, TBMM, TBMM ZC (6. Dönem), Cilt:2, s.245.

${ }^{165}$ Dr. Osman Şevki Uludağ (Konya), 19.12.1945, TBMM, TBMM TD (7. Dönem), Cilt:20, s.179.

${ }^{166}$ Hamdullah Suphi Tanriöver (İçel), 19.12.1945, TBMM, TBMM TD (7. Dönem), Cilt:20, s.190.

${ }^{167}$ Muhittin Baha Pars (Bursa), 19.12.1945, TBMM, TBMM TD (7. Dönem), Cilt:20, s.191-192.

${ }^{168}$ Muhittin Baha Pars (Bursa), 21.12.1945, TBMM, TBMM TD (7. Dönem), Cilt:20, s.294.

${ }^{169}$ Mazhar Müfit Kansu (Çoruh), 19.12.1945, TBMM, TBMM TD (7. Dönem), Cilt:20, s.184.

${ }^{170}$ Saffet Tuncay (Siirt), 22.05.1945, TBMM, TBMM TD (7. Dönem), Cilt:17, s.251.

${ }^{171}$ Mazhar Müfit Kansu (Çoruh), 22.05.1945, TBMM, TBMM TD (7. Dönem), Cilt:17, s.254.

${ }^{172}$ Sadi Yaver Ataman, Atatürk ve Türk Musıkîsi, Kültür Bakanlığı Yayınları, Ankara,1991, s.20-21.

173 İsmail Hakkı Baltacıŏlu (Kırşehir), 23.12.1946, TBMM, TBMM TD (7. Dönem), Cilt:3, s.395.

${ }^{174}$ Muhittin Baha Pars (Bursa), 29.12.1947, TBMM, TBMM TD (8. Dönem), Cilt:8, s.592.

\section{History Studies}




\section{b-Heykel}

Yabancı heykeltıraşlara yaptırılan heykellerin bize benzemediği şeklinde eleştiriler yapılmıştır ${ }^{175}$ : "Atatürk heykellerini beynelmilellere yaptırdık. Taksim'deki Canonica abidesi meydanda, Sarayburnunda, burada Güven abidesi meydanda, çok yalvarırım, o insanların hangisi bize benzer? Hadi ile Zühtü'nün yaptı̆̆ 1 bir heykel var, Barbaros heykeli. O Türktür, o kafatasını Karacaahmet'te çok görürüz.” Aynı milletvekili, daha sonra konuya bir defa daha temas ederek, "Heykelleri, iyi Türk san'atkârlarına, heykeltıraşlarına yaptıralım, dediğim zaman Canonica ve Krippel'in yaptıkları millî değil... Hasretini çektiğim Türk geleneği yalnız Türk heykeltıraşlar yapılan heykellerde vardır" diyerek yine Barbaros heykelini örnek göstermiştir ${ }^{176}$.

\section{c-Tiyatro}

Tiyatroda Türk eserlerinin sahnelenmeye başlanmamış olması ${ }^{177}$ ve yabancı rejisörlerin çalışması eleştirilmiştir ${ }^{178}$ : “... bir konservatuvarımız var. Bu konservatuvar iki kola ayrılır: opera ve tiyatro. Bugüne kadar bunların ikisi de ayn bir ecnebi rejisör tarafindan idare edilmiştir. İlk kuruluş seneleri için bu tabii olabilirdi. Çünkü nihayet 7-8 sene evvel 10-15 talebe, üç dört muallimle başlamış bir müesseseye iki mütehassıs fazla bir lüks görülebilirdi. Fakat fikrimce bunun zamanı gelmiştir... bizim bugünkü tiyatromuz durumunda bulunan bir

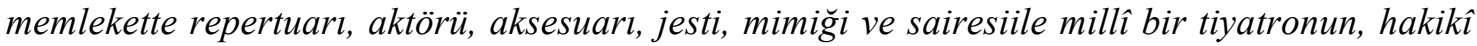
bir san'at tiyatrosunun hangi şartlarda kurulabileceğini bilen, ağırbaşll, ciddî bir san'at adamı bulmak, fikrimce hem kolay, hem ucuzdur. ” Bu temennilere rağmen tiyatronun kuruluş amacina uygun ve doğru bir istikamette olmadığı şeklindeki eleştiriler devam etmiştir ${ }^{179}$.

Tiyatronun misyonunun, "millî şahsiyetin, bir ve bütün halde seferber olduğu”, hayattan sonra hayata çok yakın bir kurumun tiyatro olduğu ifade edilmiştir ${ }^{180}$. Tiyatronun teknik itibarıyla Avrupaî bir kurum olmakla beraber kültür ve gelenek bakımından millî olması gerektiği dile getirilmiştir ${ }^{181}$.

Opera binasının ve sahnesinin uzun zamandan beri devam eden inşaatının hâlâ bitmediğ $i^{182}$ ve sahnelenen oyunlarda kullanılan dekor masrafinın çok fazla olduğu da eleştirilere konu olmuştur ${ }^{183}$. Devlet Konservatuvarı mezunlarının istihdam ve çalışma imkânlarındaki yetersizlikler de dile getirilmiştî ${ }^{184}$.

\section{7-Okul Binaları}

\section{a-Köy Okulları}

Türkiye Cumhuriyeti'nin ilköğretim hizmetleri, Osmanlı döneminden devralınan ve 1942 yılına kadar zaman zaman değişikliklere uğrayarak yürürlükte kalan 1913 tarihli Tedrisat-1 İbtidaiye Kanun u Muvakkati'ne dayanmaktadır. Bu kanunun 15. maddesinde, ilkokulların kurulması için gerekli arsanın sağlanması, okul binasının yapılması, öğretmenler, okul müdürleri ve yardımcılarının aylıklarının ödenmesi ile okul binasının onarılması, ders araç

\footnotetext{
175 İsmail Hakkı Baltacıŏlu (Kırşehir), 24.12.1945, TBMM, TBMM TD (7. Dönem), Cilt:20, s.320-321.

176 İsmail Hakkı Baltacıoğlu (Kırşehir), 20.02.1950, TBMM, TBMM TD (8. Dönem), Cilt:24, s.867.

${ }^{177}$ Behçet Kemâl Çağlar (Erzincan), 26.05.1943, TBMM, TBMM TD (7. Dönem), Cilt:2, s.235.

${ }^{178}$ Reşat Nuri Güntekin (Çanakkale), 25.05.1944, TBMM, TBMM TD (7. Dönem), Cilt:10, s.279.

${ }^{179}$ Dr. Ali Süha Delilbaşı (Kütahya), 25.05.1944, TBMM, TBMM TD (7. Dönem), Cilt:10, s.287.

${ }^{180}$ İsmail Hakk1 Baltacığlu (Kırşehir), 23.12.1946, TBMM, TBMM TD (7. Dönem), Cilt:3, s.395.

${ }^{181}$ İsmail Hakk1 Baltacıŏglu (Kırşehir), 20.12.1950, TBMM, TBMM TD (8. Dönem), Cilt:24, s.866.

${ }^{182}$ Mehmet Ali Çınar (Burdur), 25.12.1945, TBMM, TBMM TD (8. Dönem), Cilt:16, s.664.

${ }^{183}$ Dr. Adnan Adıvar (İstanbul), 17.02.1950, TBMM, TBMM TD (8. Dönem), Cilt:24, s.816.

${ }^{184}$ Suut Kemâl Yetkin (Urfa); 26.05.1943, TBMM, TBMM TD (7. Dönem), Cilt:2, s.243-244.
}

\section{History Studies}

HISTORY ST U D I ES 
gereçlerinin sağlanması, hademe ücretlerinin ödenmesi gibi konulardaki giderlerin köy ve mahalle ahalisi tarafından karşılanması zorunlu tutulmaktadır ve bu giderlerin köy veya mahallenin ait olduğu kaza, liva ya da il meclis idareleri tarafından toplanacağ belirtilmektedir ${ }^{185}$. Buna göre her köyün ihtiyar heyeti, o köyün maarif komisyonu olmuştur. Kazalarda, kaymakam başkanlığında, seçilmiş altı üyeden oluşan bir maarif komisyonu vardı. Vilâyet ve müstakil livalarda ise, mutasarrıf veya valinin başkanlığında il genel meclislerinden seçilen üç üyeden oluşan bir tedrisat-1 ibtidaiyye meclisi, maarif müfettişleri, sshhiye müdürleri ve maarif müdürleri bulunuyordu ${ }^{186}$.

Eğitim sisteminin finansmanı için vilâyet bütçeleri (Muhasebe-i hususiye) içerisinde her köy ve kasabadan tedrisat-ı ibtidaiyye vergisi alınmakta idi. Ancak bu vergilerin çok yüksek olduğu, bunun için köylülerin vergilerini ödeyemediği, hattâ bazen okulu olmayan köylerden bile vergi alındığı şeklindeki şikâyetler dile getirilmiştir ${ }^{187}$.

Yukarda ifade edilen kanun hükümlerinin uygulanmasında özellikle köylerde ciddî sıkıntılar yaşanmıştır. 1930 yılında, tedrisat-ı ibtidaiyye vergisi ile toplanan paralardan yılda ancak 250 köye okul yapılabildiği, 40.000 köyün tamamının okul binasına kavuşmasının çok uzun zaman alacağ 1 ifade edilmektedir ${ }^{188}$. İlerleyen yıllarda, köy okullarının inşaının sadece köylünün imkânlarına dayanarak yapıldığ 1 hususu, "Ciftini sürmekten men edilen, mektep parası diye 100-200 lira için davarı,sığırl, yatağı, öküzü satılan insanlar vardır...Efendi denen köylü biliyor, şehirlerin, kasabaların mekteplerinin devlet tarafindan bedava yapıldığını. Efendi hazretlerinin, ineğinin, yatağının satılarak yapıldı̆̆ını da biliyor ve bunu idrak ediyor." sözleriyle gündeme getirilmiştir ${ }^{189}$. Köylünün bu konuda gösterdiği bir fedakârlık örneği de, “...evinin çerçevesinden cam çıkarıp okul penceresine takan ve evinde mısırlarını astığ duvardaki çivilerini çıkarıp okul inşaatında kullanan bu fedakâr Türk köylüsüdür” sözlerinde ifadesini bulmuştur ${ }^{190}$.

Köylülerin tedrisat-1 ibtidaiyye vergisi ödemelerine rağmen bazı köylerde okul binalarının salma usulü ile yapıldığı iddiaları da vardır ${ }^{191}$ : "Köyün muhtar ve ihtiyar hey'etleri, köyün yapması lâzımgelen okulu üzerinde birtakım aykırllıklar ihdas ediyorlar... Köylünün kendisi için yapmak istediği hazırlık ve tertibata müdahale ediyorlar ve diyorlar ki, siz bu köyünüze şu tip okul yapacaksınız, aranızda salmayı şu ve şu nisbette taksim ettik. Köylüler para topluyorlar, işe başlıyorlar."

$\mathrm{Bu}$ eleştirilere karşılık bazı milletvekilleri de köy okullarını köylülerin yapacağını, dünyanın her tarafında bu işin böyle olduğunu ${ }^{192}$; köylerdeki okul inşaat sisteminin sadece devlet kaynaklarına bağlanmasının bu husustaki gelişmeyi engelleyeceği, dolayısıyla milletin geniş kaynaklarına dayanması gerektiğini söylemişlerdir ${ }^{193}$. Nitekim daha sonra bu konu kanunî bir hüviyet de kazanmıştır. 24 Mayıs 1948 tarihinde kabul edilen 5210 sayılı "3803, 4274 ve 4459 sayll kanunların köy okulu, ögretmen evi, köy să̆llk memurlarl ve ebeleri evleri inşa ettirilmesiyle ilgili maddelerinin değiştirilmesi ve 5012 ve 5082 sayıl kanunların kaldırılması

\footnotetext{
${ }^{185}$ F.Nurşen Kul, “Erken Cumhuriyet Dönemi İlkokul Binaları”, Mimarlık Dergisi, Sayı:360, Temmuz- Ağustos 2011, s.67.

${ }^{186}$ Mehmet Evsile, Millî Mücadele Sirasında Anadolu'da Günlük Hayat, E Yazı Yayınları, Samsun, 2015, s.32.

${ }^{187}$ Hacı Atıf Bey (Ankara), 10.02.1921, TBMM, TBMM ZC (1.Dönem), Cilt:8, s.167.

${ }^{188}$ Süleyman Sırrı Bey (Yozgat), 18.05.1930, TBMM,TBMM ZC (3. Dönem), Cilt:19, s.111.

${ }^{189}$ Emin Sazak(Eskişehir), 21.05.1945, TBMM,TBMM TD (7. Dönem), Cilt:17, s.216.

${ }^{190}$ Ali Riza İncealemdaroğlu (Zonguldak), 21.12.1945, TBMM,TBMM TD (7. Dönem), Cilt:20, s.302303.

${ }^{191}$ Mahmut Allığlu (Yozgat), 21.12.1945, TBMM,TBMM TD (7. Dönem), Cilt:20, s.303.

${ }^{192}$ Mustafa Reşit Tarakçıŏlu (Trabzon), 24.12.1946, TBMM,TBMM TD (8. Dönem), Cilt:3, s.429.

${ }^{193}$ Hüseyin Ulusoy (Niğde), 29.12.1947, TBMM,TBMM TD (8. Dönem), Cilt:8, s.602.
}

\section{History Studies}


hakkında kanun"un birinci maddesinin b fikrasında köylülere "çalışma mükellefiyeti" getirmiştir $^{194}$.

Ancak köylülerin yaptıkları ilkokul binaları çok zayıf ve eksik olmaktadır. Bu konudaki tespitler de Türkiye Büyük Millet Meclisi genel kurulunda dile getirilmiştir ${ }^{195}$ : "Son yıllar içinde bütün harcını köylümüzün temin ettiği binlerce okul binası meydana geldi. Bu kadar zahmet bahasına malolan binaların bir kismından umduğu faydayı göremeyen bu köylerin hayal sükûtu bize ne kadar üzüntü verse yeridir. Bunların arasında henüz açılma saadetine erişmeden, cephe duvarı baştan aşağı yarllmış, damı orta yerinden çökmüş, yanmış ve yarıda kalmış binaların bulunması, üzüntümüzü artıracak sebeplerdendir. "1950 yılında Millı̂ Eğitim Bakanı da, köylerdeki okul binalarının eksikleri hakkında şu sözlerle dikkat çekmektedir ${ }^{196}$ : "Yarım kalmış köy okulları, yıldan yıla tamamlanmaktadır, tamamlanmamış olanlar pek az kalmıştır. Fakat inşaatımızda daima eksiklikler bulunmaktadır. Bu sene bir mektep binası yapıyor ve açıyoruz, fakat helâsı maalesef yapılmamış bulunuyor. Onu da ertesi sene yaptırlyoruz. Bahçe duvarları yapılamıyor, birkaç sene içerisinde bahçe duvarlarını da tamamlamaya çalışıyoruz."

\section{b-Şehir Okulları}

Şehir okulları devlet ve vilâyet bütçelerinden finanse edilerek yapılmaktadır. İlköğretim için tedrisat-1 ibtidaiyye vergisinden başka, vatandaşlar üzerinde herhangi bir malî yük bulunmamaktadır. Buna rağmen şehir ve kasabalardaki okullar da bina, öğretmen, ders aracı açısından yetersiz kalmaktadır. Ülkenin değişik bölgelerinden bu konudaki sıkıntılar, Türkiye Büyük Millet Meclisi genel kurulunda dile getirilmiştir. Bunlardan bazıları şöyle tespit edilmiştir:

1942 yılı itibarıyla Ankara vilâyetinin 12 kazasının hiçbirinde orta okul yoktur ${ }^{197}$. Birinci Umumî Müfettişlik bölgesi dahilinde bulunan Diyarbakır vilâyetinde kanunen okula gitmek mecburiyetinde olan tahsil çağındaki çocukların okul ve öğretmen ihtiyacının karşılanamadığ 1 bildirilmiştir ${ }^{198}$. 1939 yılında anavatana katılan Hatay'da 53.866 çocuktan ancak 14.744'ünün okula gidebildiği, çok sayıda çocuğun Türkçe konuşamadığı, vilâyete atanan 65 öğretmenden 28'inin gelip göreve başladığı, köy ve sanat okullarındaki diğer eksikler Hatay milletvekili tarafından dilegetirilmiştir ${ }^{199}$.Muğla'ya bir Köy Enstitüsü ${ }^{200}$, Niğde’ye bir lise açılması talepleri gündeme getirilmiştir ${ }^{201}$. Erzurum'un Hınıs ilçesinde ilkokul olmadığını ${ }^{202}$, Kağızman'da 12 öğretmen bulunması gereken Kağızman Ortaokulu'nda 6 öğretmen bulunduğunu, ilgili milletvekilleri bildirmiştir ${ }^{203}$. Maraş şehir merkezinde 15 okul binasına ihtiyaç olduğu, ancak 7 binanın bulunduğu ve bunların da eski ve bir kısmının işe yaramaz olduğunu Maraş milletvekili ifade etmiştir ${ }^{204}$.

\footnotetext{
${ }^{194}$ T.C. Resmî Gazete, 31 May1s 1948, Sayı:6919, s.14109.

${ }^{195}$ Faruk Nafiz Çamlıbel (İstanbul), 29.12.1947, TBMM,TBMM TD (8. Dönem), Cilt:8, s.578.

${ }^{196}$ Millî Eğitim Bakanı Tahsin Banguoğlu (Bingöl), 20.02.1950, TBMM,TBMM TD (8. Dönem), Cilt:24, s.855.

${ }^{197}$ Belk1s Bayhan (Ankara), 26.05.1942, TBMM,TBMM ZC (6. Dönem), Cilt:25, s.311.

${ }^{198}$ General Kâzım Sevüktekin(Diyarbakır), 26.05.1943, TBMM,TBMM ZC (7. Dönem), Cilt:2, s.234.

${ }^{199}$ General Eyüp Durukan (Hatay),25.05.1945, TBMM,TBMM ZC (7. Dönem), Cilt:10, s.273-274.

${ }^{200}$ Orgeneral İzzeddin Çalışlar (Muğla), 25.05.1944, TBMM,TBMM ZC (7. Dönem), Cilt:10, s.283.

${ }^{201}$ Şükrü Süer (Niğde), 25.02.1949, TBMM,TBMM TD (8. Dönem), Cilt:16, s.668.

${ }^{202}$ General Vehbi Kocagüney (Erzurum), 25.02.1949, TBMM,TBMM TD (8. Dönem), Cilt:16, s.665.

${ }^{203}$ Feyzi Aktaş (Kars), 20.02.1950, TBMM,TBMM TD (8. Dönem), Cilt:24, s.860.

${ }^{204}$ Emin Soysal (Maraş), 17.02.1950, TBMM,TBMM TD (8. Dönem), Cilt:24, s.810.
} 


\section{8-Okullaşma ve Okuryazar Oranları}

Okullaşma ve okuryazar oranları hakkında değişik zamanlarda farklı rakamlar telâffuz edilmiştir. Gerek akademik çalışmalar sonunda elde edilen rakamlar, gerekse Türkiye Büyük Millet Meclisi kürsüsünden ifade edilen rakamlardan bazıları şöyledir:

1930 yılında tahsil çağındaki çocukların yüzde 33'ü okula alınabilmiştir. Bu oran köylerde yüzde 16 , şehirlerde yüzde $53{ }^{\prime}$ tür $^{205}$. 1950 yllında, ilköğretimde okula alınan çocuk miktarı yüzde 60 olmuştur ${ }^{206}$.

Okullardaki başarı oranları da düşüktür. Ortaokullarda 1933-1944 yılları arasında mezun olanların oranı yüzde $17 \mathrm{iken}^{207}, 1947$ yılında bu oran yüzde 25 olmuştur ${ }^{208} .1950$ yılında yüzde kırka yükselmiştir ${ }^{209}$. Liselerdeki başarı oran1 1950 yılında yüzde 30'dur. Öğrencilerin çoğu 2 veya 3 sene uzatarak mezun olmaktadırlar ${ }^{210}$.

Okuryazar oranları ise, 1924 yılında yüzde 2-3 olarak ifade edilmektedir ${ }^{211}$. Bu rakam biraz mübalâğalı olarak görülse de başka kaynaklarda da buna benzer bilgiler yer almaktadır. Daha 1921 yılında, silâh altındaki askerlerin yüzde doksan beşinin okuryazar olmadı̆̆ Malatya milletvekili Lütfi Bey tarafindan Türkiye Büyük Millet Meclisi'nde dile getirilmiştir ${ }^{212}$.

1927 nüfus sayımında okuryazar olanların oranı yüzde 11 olarak görülmektedir ${ }^{213} .1927$ yılı okuryazar oranı ile ilgili bilimsel çalışmalarda bazı istatistik verilere de ulaşılmıştır. Buna göre Türkiye'de, 1927 yılında okuryazarlık oranı, kadınlarda yüzde 4, erkeklerde yüzde 13 ve genel nüfusa göre yüzde 8.16 idi. Bunun yüzde 5-6'sı eski yazıyı bilen Türkler'de, geri kalanı gayrimüslimlerde ve öteki dillerde idi $^{214}$.

Aynı dönemde bu oranların Brezilya'da yüzde 14,8; Rusya'da yüzde 27,6 olduğu

Volume 11

Issue 2

A tribute to

Prof. Dr.

Mehmet Ali

ÜNAL

April

2019 bilinmektedir ${ }^{215}$. Harf İnkılâbından sonra 1935 yılında okuryazar oranı Türkiye'de deyüzde 20,4'e yükselmiştir ${ }^{216} .1947$ yılında yüzde 36,9 ${ }^{217}, 1950$ yılında yüzde 40 olmuştur ${ }^{218}$.

\section{9-Eğitim Hayatında Yaşanan Problemler \\ a-Harf İnkılâbının Günlük Hayata Yansımaları}

1353 sayı 1 Kasım 1928 tarihli Türk Harflerinin Kabul ve Tatbiki Hakkında Kanun ile, Türkiye'de Arap harflerinin kullanılmasından vazgeçilerek Lâtin esaslı yeni Türk harfleri yürürlüğe konmuştur. $\mathrm{Bu}$ kanunun 2.maddesinde "Bu Kanunun neşri tarihinden itibaren

\footnotetext{
${ }^{205}$ Maarif Vekili Cemâl Hüsnü Bey (Gümüşhane), 18.05.1930, TBMM,TBMM ZC (3. Dönem), Cilt:19, s.104.

${ }^{206}$ Millî Eğitim Bakanı Tahsin Banguoğlu (Bingöl), 20.02.1950, TBMM,TBMM TD (8. Dönem), Cilt:24, s.849.

${ }^{207}$ Emin Soysal (Maraş), 24.12.1946, TBMM,TBMM TD (8. Dönem), Cilt:3, s.454-455.

${ }^{208}$ Niyazi Çıtakoğlu (Çanakkale), 29.12.1947, TBMM,TBMM TD (8. Dönem), Cilt:8, s.606.

${ }^{209}$ Kâmil İdil (Maraş), 17.02.1950, TBMM,TBMM TD (8. Dönem), Cilt:24, s.805.

${ }^{210}$ Millî Eğitim Bakanı Tahsin Banguoğlu (Bingöl), 20.02.1950, TBMM,TBMM TD (8. Dönem), Cilt:24, s.851.

${ }^{211}$ Saracoğlu Şükrü Bey (İzmir), 25.02.1924, TBMM,TBMM ZC (2. Dönem), Cilt:6, s.335-336.

${ }^{212}$ Lütfi Bey (Malatya), 24.09.1921, TBMM,TBMM ZC (1.Dönem),Cilt:13, s.10.

${ }^{213}$ Yahya S. Tezel, Cumhuriyet Döneminin İktisadî Tarihi (1923-1950),Türkiye İş Bankası Kültür Yayını, İstanbul, 2015, s.118.

214 İsmet Türkmen; Kastamonu Halkevi Kastamonu Halkevi Ve Türkiye' in Modernleşme Sürecine Katkıları 1932 1951 (2013), Berikan Yayınevi, Ankara 2013, s. 31-33.

${ }^{215}$ Cumhuriyet Dönemi Türkiye Ekonomisi 1923-1978, Akbank Kültür Yayını, İstanbul,1980, s.5.

${ }^{216}$ Mustafa Albayrak,"Millet Mekteplerinin Yapısı ve Çalışmaları (1928-1935)", Atatürk Araştırma Merkezi Dergisi, Cilt:X, Temmuz 1994, Sayı:29, s.482.

${ }^{217}$ Reşat Aydınlı (Denizli), 25.02.1949, TBMM,TBMM TD (8. Dönem), Cilt:16, s.641.

${ }^{218}$ Muhittin Adil Binal (Konya),17.02.1950, TBMM,TBMM TD (8. Dönem), Cilt:24, s.767.
}

\section{History Studies}


devletin bütün daire ve müesseselerinde ve bilcümle şirket, cemiyet ve hususî müesseselerde Türk harfleriyle yazılmış olan yazıların kabulü ve muameleye konulması mecburidir" ifadesi yer almaktadir ${ }^{219}$.

Bugün Millî Eğitim Bakanlı̆̆ı’nın Web sayfasında “Harf İnkllâbı”nın gerekçesi şu şekilde ifade edilmektedir ${ }^{220}$ :

1-Okuma ve yazmanın herkese kolaylıkla öğretilmesi,

2-Bilgi ve kültürün ülkenin her yanına yayılması,

3-Türk dilinin bağımsızlı̆̆ının sağlanması,

4-Türkçenin Arap harfleriyle yazılışındaki zorluğun bir an önce giderilmesi,

5-Türk dilinin yapısına uymayan Arap harflerinden kurtarılması ve yapısına en uygun Lâtin esasından alınan yeni Türk harflerinin uygulanması amacıyla "Türk Harf Ínkılâbı" yapılmasının gereğine inanmıştır.

Harf İnkılâbının Türk toplumu üzerindeki sosyal ve kültürel etkileri ile yukardaki hedefler istikametindeki gelişmeler ve bugün varılan sonuçlar, konunun uzmanı olan bilim adamları tarafından akademik çalışmalarla ortaya konulmuştur ${ }^{221}$.

Ancak, Harf İnkılâbı, toplumda tam olarak yerleşinceye kadar bazı sıkıntılar da yaşanmıştır ki bunlar zaman zaman Türkiye Büyük Millet Meclisi genel kurulunda dile getirilmiştir. İlk olarak daha 1932 yılında yeni harflerle yazılmış kitaplardan oluşan bir kütüphane kurma ihtiyacı gündeme gelmiştir ${ }^{222}$ :“...harflerimiz yenidir, harflerimiz yepyenidir ve millî kütüphanemiz baştan başa tesis edilmeye muhtaçtır. Her yaşta ve meslekte olan insanların ve çocukların okuyacağl eser yoktur. Kitapsız medeniyet olmaz ve kitapsız bir dil olmaz. Bir de imlâmızın inzibatı yoktur. Harf inkılâbımızın istihdaf ettiği (hedeflediği) maksatlardan biri de imlâmızın inzibatını temin etmek idi. El'an imlâmızın inzibatı teessüs etmemiştir. Halbuki yeni harfler bu inzibatı temine çok müsaittir. Kezalik dilimizi, harflerimizin ve inkılâpçı zihniyetimizin icabatıyla telif edecek mesai yoktur." Aynı sıkıntıları bir yıl sonra o günün Millî Eğitim Bakanı Reşit Galip Bey de ifade etmektedir ${ }^{223}$ : “... eski kütüphanelerimizin mes'ut harf inkılâbımız dolayısıla kâmilen ortadan kalkacă̆ı ve millî kütüphanemizin henüz kurulmak yolunda bulunmuş olmasıdır ve bu sebepledir ki lisan bilen bir gençlik yetiştiremezsek ve bunu acilen yapamazsak istikbâl için kitapsız kalmış bir nesle vilâyetlerin, belediyelerin hükümet ve devletin idaresini bırakacă̆ımız bir devir gelecektir." Kütüphane sıkıntısı, aradan 9 y1l geçtikten sonra bir defa daha dile getirilmiştir" ${ }^{224}$ : İstanbul Üniversitesinde ve Ankara'daki yüksek tahsil müesseselerimizde birer kütüphane vardır. Fakat memleketimizde tam manasıyla modern, bütün teşkilâtı havî ve dünya ilmî neşriyatını muntazam takip eder bir kütüphane maalesef henüz mevcut değildir. ” Bu şekilde bir kütüphane için kitap toplama faaliyetleri 15 Nisan 1945 tarihinde Millî Eğitim Bakanlığı Yayım Müdürlüğünde başlamıș, bu faaliyetler 29 Mart 1950 tarih ve 5632 sayılı Millî Kütüphane Kuruluşu Hakkında Kanun ile bir kütüphane halini almıştır ${ }^{225}$.

\footnotetext{
${ }^{219}$ T.C.Resmî Gazete, 3 Kasım 1928, Sayı:1030, s.6001.

${ }^{220}$ mevzuat.meb.gov.tr

${ }^{221}$ Zeynep Korkmaz, “Alfabe Devriminin Türk Toplumu Üzerindeki Sosyal ve Kültürel Etkileri”, Turkish Studies, Volume 4/3 Spring 2009, s.1469-1480.

${ }^{222}$ İbrahim Alâeddin Bey (Sinop), 25.06.1932, TBMM,TBMM ZC (4. Dönem), Cilt:9, s.316.

${ }^{223}$ Maarif Vekili Reşit Galip Bey (Aydın), 17.05.1933, TBMM,TBMM ZC (4. Dönem), Cilt:15, s.147.

${ }^{224}$ Kasım Gülek (Bilecik), 26.05.1942, TBMM,TBMM ZC (6. Dönem), Cilt:25, s.321.

${ }^{225}$ T.C. Resmî Gazete, 29 Mart 1950, Say1:7469, s.18201.
} 
Dil İnkılâbı çerçevesinde yeni bulunan kelimelerin kullanılması ile yazılan okul kitaplarındaki dilin çok dağınık olduğ ${ }^{226}$, yeni harflere göre bir gramer oluşturulamadığı için çocukların okul kitaplarından Türkçe öğrenemedikleri şikâyet konusu olmuştur ${ }^{227}$. Evde konuşulan Türkçe ile okulda konuşulan Türkçenin birbirinden farklı oluşunun kuşaklar arasındaki anlaşmayı zorlaştırdığ ${ }^{228}$; okulda çocuğu olan anne babaların, kitapların dilini anlamadıkları için çocuklarının derslerine yardımcı olamadıkları hususları da eleştirilmiştir ${ }^{229}$. Bu eleştirilere karşı, Türkiye Cumhuriyetini kuran büyük inkılâbın ideolojisinin eğitim hayatına da girmesi gerektiği ${ }^{230}$; "dil devriminin yolunu tutmuş ve hızını bulmuş olduğu, bunu durdurmanın mümkün olmadığı" şeklinde cevaplar verilmiştir ${ }^{231}$.

\section{b-Ders Müfredat Programlarındaki İstikrarsızlık}

Ders müfredat programlarında sık sık yapılan değişiklikler, öğrencilere ve öğretmenlere güçlük verdiğ $i^{232}$; bu durumun senelerden beri daimî bir okutma sistemine girmediğimizi ve yetiştirmekte olduğumuz talebenin randımanının yükselmesine engel olduğu ifade edilmiştir ${ }^{233}$. Bu şikâyetler uzun yıllar gündemde kalmış, 1947 yılında yapılan bir açıklamada, "Cumhuriyet hayatımızda üç defa sistem, altı defa program, dört defa ıstılah ve sayısız defalar da ders kitapları değiştirdik ki, bu değişikliklerden sadece çocukların değil, öğretmenlerin bile başı dönmüştür" sözleriyle eleştirilmiştir ${ }^{234}$.

Eğitim hayatındaki aksaklıklar başından itibaren dikkat çekmeye başlamıştır. 1935 yılında Maarif Bakanı Abidin ÖZMEN, maarif plânının ilkokuldan başlayıp, sonraki kademelere gitmesi gerektiğini ifade etmiştir ${ }^{235}$. Ancak, 1947 yılında Faruk Nafiz ÇAMLIBEL, millî eğitimde programların değil, şahısların belirleyici olduğunu eleştirmiştir ${ }^{236}$ : “Ötedenberi devam eden idare tarzımıza dikkat edilince Millî Ĕ̈itimde programlardan ziyade şahısların nâzım olduklarını görüyoruz. Her bakanın kendi buluşlarını tatbik etmeleri bir teamül haline geldiğindendir ki, Millı̂ Ĕgitim zaman zaman birbirinden ayrı şekillerle yüksek huzurunuza çıkmıştı. " Bunların sonucunda okullarda eğitimin yeterli olmadığ 1 defalarca dile getirilmiştir ${ }^{237}$. Üniversitelerin, liselerden öğrencilerin bilgilerini, liseler ortaokullardan gelen, ortaokullar da ilkokullardan gelen öğrencilerin bilgilerini yetersiz bulmuşlardır ${ }^{238}$. Eğitim hayatının problemleri, 1947 yılında, başka bir milletvekili tarafından şu şekilde sıralanmıştır ${ }^{239}$ :

1- Sistem ve icraatta kararsızlık ve programsızlık,

2- Eleman seçiminde isabetsizlik,

3- Yapılan her icraatta işin ruhundan ziyade gösterişe önem vermek.

\footnotetext{
${ }^{226}$ Maarif Vekili Hasan Âli Yücel (İzmir), 27.05.1941, TBMM,TBMM ZC (6. Dönem), Cilt:18, s.221.

${ }^{227}$ Sezai Uzay (Balıkesir), 15.05.1939, TBMM,TBMM ZC (6. Dönem), Cilt:2, s.251.

${ }^{227}$ Maarif Vekili Reşit Galip Bey (Aydın),17.05.1933, TBMM,TBMM ZC (4. Dönem), Cilt:15, s.147.

${ }^{228}$ Muhitti Baha Pars (Bursa), 29.12.1947, TBMM,TBMM TD (8. Dönem), Cilt:8, s.591-592.

${ }^{229}$ Kâmil İdil (Maraş), 17.02.1950, TBMM,TBMM TD (8. Dönem), Cilt:24, s.805.

${ }^{230}$ Aka Gündüz (Ankara), 26.05.1936, TBMM,TBMM ZC (5. Dönem), Cilt:11, s.244.

${ }^{231}$ Hasan Reşit Tankut (Maraş), 29.12.1947, TBMM,TBMM TD (8. Dönem), Cilt:8, s.608.

${ }^{232}$ Süreyya Örge Evren (Bitlis), 25.05.1939, TBMM,TBMM ZC (6. Dönem), Cilt:2, s.263.

${ }^{233}$ Şehime Yunus (İzmir), 25.05.1939, TBMM,TBMM ZC (6. Dönem), Cilt:2, s.264.

${ }^{234}$ Niyazi Çıtakoğlu (Çanakkale), 29.12.1947, TBMM,TBMM TD (8. Dönem), Cilt:8, s.607.

${ }^{235}$ Maarif Bakanı Abidin Özmen (Aydın),25.05.1935, TBMM,TBMM ZC (5. Dönem), Cilt:3, s.259.

${ }^{236}$ Faruk Nafiz Çamlıbel (İstanbul), 29.12.1947, TBMM,TBMM TD (8. Dönem), Cilt:8, s.577.

${ }^{237}$ 25.05.1939, TBMM,TBMM ZC (6. Dönem), Cilt:2, s.249-251.

${ }^{238}$ Faruk Nafiz Çamlıbel (İstanbul), 29.12.1947, TBMM,TBMM TD (8. Dönem), Cilt:8, s.579-580.

${ }^{239}$ Niyazi Çıtakoğlu (Çanakkale), 29.12.1947, TBMM,TBMM TD (8. Dönem), Cilt:8, s.605-608.
}

\section{History Studies}


Şehir okulları ile köy okullarının eğitim seviyesinin farklı olduğu görülmektedir. Köy okullarının da şehir okulları seviyesine getirilmesi talep edilmiştir ${ }^{240}$. Öğretmen yokluğundan dolayı köy okulları dört sınıftan üç sınıfa ${ }^{241}$; şehir ilkokullarının altı sınıftan beş sınıfa düşürülmesi $^{242}$ ve köy kızlarının okutulmaması eleştirilmiştir ${ }^{243}$. Köylerde üç sınıflı okul uygulaması, 1950 yılında devam etmiştir ${ }^{244}$.

Eğitim sisteminin önemli bir yanlışının de ezbere dayalı oluşu ve imtihan sistemindeki hatalar olduğu görülmektedir. Bu konularda milletvekillerinden şikâyetler gelmiştir. Bunlardan birinde ezbercilik eleştirilmektedir ${ }^{245}$ : "Halihazır okul programları, ezberciliği teşvik edecek şekilde yüklüdür. Kuru bilginin hakiki bilgi olduğunu sananları yaptıkları bir program mahiyetindedir. Faydası olmayan, kullanılmayan, tatbik kabiliyeti bulunmayan bilgi, değildir. Gençlerin kabiliyetlerini gelişstirmeyen, enerjilerini içten tahrik etmeyen, kafalarını işletmeyen bilgi, bilgi değildir. ” Diğerinde de imtihan sisteminden şikâyet edilmektedir ${ }^{246}$ : “... bir derdimiz var, ona ezelî dert derler, o da imtihan usûlüdür. Bizim bugün tatbik ettiğimiz imtihan usûlügayrıinsanidir, antisiyantifiktir, antipsikolojiktir...Bunları ilmîleştirelim."

Okullarda devem problemi de dikkat çekilen bir konu olmuştur ${ }^{247}:$ “... liselerde Milli Eğitim Bakanlığl, okula devamsızlığı 60 gün olarak düşünmüş̧ür. Bunun için okula devam etmeyen çocuklar devamsızlıkları dolayıslyla kanaat notu alamazlar. Böyle çocuklar meselâ 58 veya 59 gün okula gelmemekte, 60. Gün gelmektedir. Bu suretle okul idaresi öğrenciyi zaman içinde görerek o talebe hakkında bir şey yapamamaktadır."

\section{c-Okulların Sağlık Problemleri}

Okullarda öğrencilerin ve öğretmenlerin sağlık problemleri ile ilgilenmek üzere okul tabiplikleri adı altında bir teşkilât mevcuttur. Ancak bunlara çok cüzî bir maaş ödendiği için, başka işlerle meşgul olmaktadırlar ve okullarda çok az bir zaman kalmaktadırlar. Okulda bulundukları zamana tesadüf eden bir öğrenci hastalandığı zaman öylesine bir muayene etmekte veya öğretmenlerden hasta olanlara rapor vermekten başka bir katkıları olmamaktadır ${ }^{248}$. Bu konudaki eksiklikler, Millî Eğitim Bakanı Tahsin BANGUOĞLU tarafından da kabul edilmiştir ${ }^{249}$ : “... mektep doktorları işlerinde geriyiz. Çünkü mektep doktorlarına çok cüz'î bir ücret vermekteyiz. Onun için başka bir işle meşgul olan doktorlardan yardım temin etmekteyiz. Halbuki bütün günlerini mektebe hasredecek doktorlara ihtiyacımız vardır. Bu bir kadro meselesidir. Mekteplerimizde geniş bir sağllk kadrosuna ihtiyaç vardır." Ögrencilerin, hasta olan ögretmenlerden hastalık kaptığı şeklindeki bir örnek de şu şekilde ifade edilmiştir ${ }^{250}$ : “... sizin mektep yaşında bir çocuğunuz olsa, veremli bir hoca ile kapalı bir odaya kapayarak, soba ile mangal başında bulunmasına, ders almasına müsaade eder misiniz? Buradaki bütün doktorlar da bilir. Hoca öhö dedi mi, ăgzından çıkan mikrop 9 metre öteye gider. 7-8 yaşındaki çocuklar veremi çok çabuk alırlar. Çocukla veremli hocanın baş başa

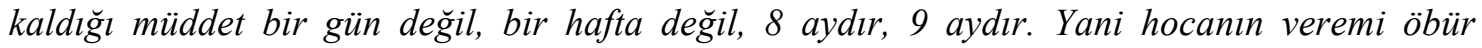

\footnotetext{
${ }^{240}$ Hüseyin Ulusoy (Niğde), 25.05.1944, TBMM,TBMM ZC (7. Dönem), Cilt:10, s.280.

${ }^{241}$ Emin Bey (Eskişehir), 17.05.1933, TBMM,TBMM ZC (4. Dönem), Cilt:15, s.147.

${ }^{242}$ Refik Şevket Bey (Manisa),17.05.1933, TBMM,TBMM ZC (4. Dönem), Cilt:15, s.140.

${ }^{243}$ Org. İzzettin Çalışlar (Muğla), 27.05.1941, TBMM,TBMM ZC (6. Dönem), Cilt:18, s.215.

${ }^{244}$ Millî Eğitim Bakanı Tahsin Banguoğlu (Bingöl), 20.02.1950, TBMM,TBMM TD (8. Dönem), Cilt:24, s.849.

${ }^{245}$ Reşat Aydınlı (Denizli), 25.02.1949, TBMM,TBMM TD (8. Dönem), Cilt:16, s.642.

${ }^{246}$ İsmail Hakkı Baltacıŏglu (Kırşehir), 18.02.1950, TBMM,TBMM TD (8. Dönem), Cilt:24, s.834.

${ }^{247}$ Hasene Ilgaz (Çorum), 25.12.1949, TBMM,TBMM TD (8. Dönem), Cilt:16, s.654.

${ }^{248}$ Kâmil İdil (Maraş), 29.12.1947, TBMM,TBMM TD (8. Dönem), Cilt:8, s.588.

${ }^{249}$ Millî Eğitim Bakanı Tahsin Banguoğlu (Bingöl), 20.02.1950, TBMM,TBMM TD (8. Dönem), Cilt:24, s. 852.

${ }^{250}$ Dr. Saim Ali Dilemre (Rize), 25.05.1939, TBMM,TBMM ZC (6. Dönem), Cilt:2, s.249.
}

\section{History Studies}

\section{(}


memurların veremine benzemez...Verem noktasında çocukların iki düşmanı vardır, biri süt, diğeri hoca. Süt kaynatılır ama hoca kaynatılamaz. "Okullarda veremle mücadele mecburiyeti 1945 yılında da aynı milletvekili tarafından dile getirilmiştir ${ }^{251}$.Zaman zaman okullarda ortaya çıkan hastalık ve diğer sağlık problemleri ile de mücadele edilmiştir. 1928 yılında çocuklarda görülen kızıl hastalığ ile mücadele edilmiş ${ }^{252}$, 1946 yılında okullarda bit ile mücadele edilmesi istenmiştir ${ }^{253}$.

Bununla birlikte öğrencilerin sağlik problemlerinin çözümü için öğretmenlerin okulda yemek pişirip muhtaç öğrencilere yedirdikleri de görülmektedir ${ }^{254}$ :"Çocukların bir kısmının sağllklarl iyi değildir. Çok şayan-ı şükrandır, Eğitim Bakanımızın bir yardım diye hal ve vaziyetleri iyi olanlardan para topluyorlar, Kızlay yardım ediyor ve bu suretle fakir çocukların öğle yemeklerine dikkat ediliyor, bunlara hususî yemek pişiriliyor. Geçenlerde, İstanbul'da Üsküdar'da yemek zamanında bir okula gideyim, kimsenin haberi yok dedim kapıdan girdim. Baktım pencerelerden, çocuklar, mini miniler oturmuşlar, başlarında bir bayan ögretmen. $O$ muhtaç çocuklar için olan yemeğin dăgıtımına nezaret ediyor.” 1944 y1lında, Millî Eğitim Bakanı Hasan Âli YÜCEL, Çocuk Esirgeme Kurumu, Kızılay, Halkevleri, yardım sevenler, okul himaye hey'etleri, kooperatifler, okul yardım kollarının Türkiye'de muhtelif okullarda 127.451 öğrenciye yemek, elbise ve ayakkabı yardımı yaptıklarını açıklamıştır ${ }^{255}$.

Yatılı okullarda öğrencilerin yiyeceği yemekleri pişiren, odaların temizliğini yapan,

HISTORY

STUDIES

647

Volume 11

Issue 2

A tribute to

Prof. Dr.

Mehmet Ali

ÜNAL

April

2019

yatakları düzelten, pencereleri açarak binanın havalanmasını sağlayan "Yatı Anaları" denilen yaşlı kadınlar görev yapmışlardır ${ }^{256}$.

\section{0-Eğitim Politikasının Gayesi ve İdeolojisi}

1949 yılına gelindiği zaman eğitim politikalarının gayesi 4 noktada toplanmıştır. Bunlar:

1-Milleti ümmîlikten ve cehaletten kurtarmak,

2-Eğitim imkânlarının yalnız bu imkânları satın almaya muktedir vatandaşlara değil, kabiliyeti olan herkesin faydalanacağı, her Türk'e eğitim imkânlarının verilmesi,

3-Tahsilin lüks bir meta olmaktan çıkarılması, demokrasi terbiyesinin verilmesi,

4-Eğitim yaşını geçirmiş olanlara da bu imkânın sağlanması olarak tespit edilmiştir ${ }^{257}$.

Eğitim hizmetlerine, öğrencileri günün getirdiği bilgi ile donatmaktan başka bazı misyonlar da yüklenmiştir. Bunlardan birinde, maarifimizin asker nesil yetiştirmesi gerektiğ $i^{258}$; diğerinde, ilköğretimin vazifesinin Türk’e Türklüğünü öğretmek olduğu ifadeedilmiştir ${ }^{259}$.

1928 yılında Bozkurt Derneği Teşkilâtı çerçevesinde okullarda öğrencilere askerî eğitim ve izcilik dersleri verilmeye başlanmıştır. Maarif Vekili Mustafa Necati Bey, bu konudaki görüşlerini şu şekilde açıklamıştır ${ }^{260}$ :"Mekteplerimizde tedrisata ehemmiyet vermekle beraber gençliğimizin bedenî kuvvetlerini artırmak ve askerî bilgi ve kabiliyetlerini yükseltmek ile de

\footnotetext{
${ }^{251}$ Dr. Saim Ali Dilemre (Rize), 24.12.1945, TBMM,TBMM TD (7. Dönem), Cilt:20, s.346.

${ }^{252}$ Sihhiye Vekili Doktor Refik Bey (İstanbul), 22.04.1928, TBMM,TBMM ZC (3. Dönem), Cilt:3, s.200.

${ }^{253}$ İsmail Hakkı Baltacıŏlu (Kırşehir), 23.12.1946, TBMM,TBMM TD (8. Dönem), Cilt:3, s.392.

${ }^{254}$ General A. Naci Tinaz (Bursa), 21.12.1945, TBMM,TBMM TD (7. Dönem), Cilt:20, s.296.

${ }^{255}$ Maarif Vekili Hasan Âli Yücel (İzmir), 22.05.1944, TBMM,TBMM ZC (7. Dönem), Cilt:10, s.292-293.

${ }^{256}$ Maarif Vekili Reşit Galip Bey (Aydın), 17.05.1933, TBMM,TBMM ZC (4. Dönem), Cilt:15, s.149.

${ }^{257}$ Reşat Aydınlı (Denizli), 25.02.1949, TBMM,TBMM TD (8. Dönem), Cilt:16, s.638.

${ }^{258}$ Feridun Fikri Düşünsel (Bingöl), 27.05.1941, TBMM,TBMM ZC (6. Dönem), Cilt:18, s.211.

${ }^{259}$ İsmail Hakkı Baltacıoğlu (Kırşehir), 23.12.1946, TBMM,TBMM TD (8. Dönem), Cilt:20, s.389.

${ }^{260}$ Maarif Vekili Mustafa Necati Bey (Aydın), 22.04.1928, TBMM,TBMM ZC (3. Dönem), Cilt:3, s.206.
}

\section{History Studies}


meşgul olduk. Bunun için Müdafaa-i Milliye Vekâleti ve Erkân-ı Harbiye-i Umumiye ile elele vererek liselerimizde ve muallim mekteplerimizde yeni nesle bu malûmatı verdik. İzcilik işlerine ehemmiyet atfetmekteyiz. Cilız, hastalıkl, atıl fertlerden mürekkep bir cemiyet yerine uyanık, faal ve tuttuğunu koparır gençler için çalışıyoruz... Yazın askerî kamplarda çadır altında silâhlarıyla çalışan bu gençliğin manzarası hakikaten iftiharla göğüs kabartacak kadar ümitbahştır. (Bozkurt Derneği) teşkilâtı kanunuyla mektep haricindeki gençlerin de tarz-ı hayata girmelerini temin edeceğiz." Bu kurslarla, yazın iki ay süreyle açılan kamplarda, çadırlarda kalan öğrencilere askerî eğitim verildiği bilinmektedir ${ }^{261}$.

İkinci olarak eğitimin milliyetçi amaçları dikkat çekmektedir ${ }^{262}$ : "Çocuklarımıza gözlerini açtığı dakikadan itibaren Frenk şapkası değil, Türk simasını göstermek lâzımdır, çocuklarımıza ilk konuşmaya başlarken ana lisanını öğretmeden evvel ilk terbiyeye başka bir milletin ismini sokmak demektir ki, buna Nasyonalist Türkiye asla müsaade edemez. Maarif Vekâleti buna çok büyük ehemmiyetle sarlld ve muvaffakiyetle tatbik ediyor." Bu konuda Millî Eğitim Bakanı da, "Birçok memleketlerde, birçok anasır, birçok propagandalara maruzdur. Fikir hayatı mevcut olan her memlekette bu böyledir. Binaenaleyh bütün vatandaşlar gibi gençler de buna maruzdur ve tabiatı ile propagandactlar gençliğe daha ziyade ehemmiyet atfediyorlar. Çünkü gençliğin dimă̆ını elde tutmak daha kolaydır. Fakat itminanla (emin olmak) söyleyebilirim ki, gençliğimizde milliyetçilikten başka hiçbir propaganda kök tutmamaktadır." sözleriyle düşüncelerini ifade etmiştir ${ }^{263}$.

Bunlardan başka, okullarda Kemalizm propagandası yapılması gerektiği üzerinde de durulmuştur"264: "Hakikaten Kemalizm, altı ok iyiden iyiye millete telkin edilmiş değildir. Maarif Vekâletimizden çok rica ederiz, okullarda genç dimağlara Kemalizmin yayılmasına ve yerleşmesine himmet buyursunlar. İcap eden konferanslarla yolumuzun ne olduğunu iyiden iyiye ışıtalım ki, hiç yanlışlığa mahal kalmasın." Bu taleplere karşılık Millî Eğitim Bakanı Hasan Âli YÜCEL, memleket çocuklarının rejime, Atatürk'e ve millî şefimize bağl1lıklarından emin olduğunu, okullara Kemalizmden başka bir ideoloji sokmamak gerektiğini ifade etmiştir ${ }^{265}$.

Türkiye Cumhuriyeti'nin propagandasının yapılması için radyo yayınları da kullanılmıştır. $\mathrm{Bu}$ konudaki talep, “... radyo davası elimizde büyük bir propaganda davasıdır...radyo saatlerinin bilhassa asıl büyük kitlenin radyo dinleyebileceği zamanlara göre ayarlanmasını ve bu çeşit neşriyatın o saatlere girmesini daha münasip görüyoruz" sözleriyle dile getirilmiş ${ }^{266}$; Basın Yayın Genel Müdürü tarafından şu sözlerle cevaplandırılmıştır' ${ }^{267}$ : "Propaganda' bakımından yapılacak neşriyata gelince, şunu arz edeyim ki, 10 yabancı dilde neşriyat yapılmaktadır. Yakın Balkan memleketleri, Yakın Şark memleketlerine ve hattâ Hindistan'a yapılan yayılar bu meyandadır."

Radyo yayınlarının hangi konulara ağırlık vermesi gerektiği de bir milletvekili tarafından şu şekilde ifade edilmiştir ${ }^{268}$ :

1-Çocuklarımızı yakından ilgilendiren yayına daha fazla önem versinler ve bu yayını dikkatle gözden geçirmeden, Kemalist ölçüye vurmadan yapmasınlar,

\footnotetext{
${ }^{261}$ Maarif Vekili Mustafa Necati Bey (Aydın), 22.04.1928, TBMM,TBMM ZC (3. Dönem), Cilt:3, s.214.

${ }^{262}$ Refik Şevket Bey (Manisa), 25.06.1932, TBMM,TBMM ZC (4. Dönem), Cilt:9, s.315.

${ }^{263}$ Maarif Vekili Hikmet Bey (Manisa), 29.05.1934, TBMM,TBMM ZC (4. Dönem), Cilt:22, s.441.

${ }^{264}$ İzzet Ulvi Aykurt (Eskişehir), 25.05.1944, TBMM,TBMM ZC (7. Dönem), Cilt:10, s.278.

${ }^{265}$ Maarif Vekili Hasan Âli Yücel (İzmir), 22.05.1944, TBMM,TBMM ZC (7. Dönem), Cilt:10, s.290.

${ }^{266}$ Mehmet Fahrettin Ecevit (Kastamonu), 19.12.1945, TBMM,TBMM TD (7. Dönem), Cilt:20, s.181.

${ }^{267}$ Basın ve Yayın Umum Müdürü N. V. İlkin, 18.12.1945, TBMM,TBMM TD (7. Dönem), Cilt:20, s.188.

${ }^{268}$ Şükrü Sökmensüer (Erzurum), 22.05.1945, TBMM,TBMM TD (7. Dönem), Cilt:17, s.249.
}

\section{History Studies}


2- Cumhuriyet nasıl bir vatan teslim aldı ve ne yaptı, ne yapıyor? Mütemadiyen söylesinler. Yapılanları unutturmasınlar,

3- Çalışkan vatandaşları Türk milletine tanıtan konuşmalar yaptırsınlar.

Radyoda haberlerin düzgün bir şekilde verilmesi ${ }^{269}$, batı dillerinden alınan kelimelerin fazla kullanılmaması gerektiğine dikkat çekilmiştir ${ }^{270}$. Bu eleştirilere cevap olarak Basın ve Yayın Genel Müdürü, radyo yayınlarını denetleyen bir komisyon bulunduğunu ve bu komisyonda Genelkurmay Başkanlığı'nın, Millî Eğitim Bakanlığı'nın ve Cumhuriyet Halk Partisi'nin birer üyesi bulunduğunu, programların bu komisyonun kontrolünden sonra yayınlandığını söylemiştir ${ }^{271}$.

Radyodan başka gazetelerin de inkılâbımızı bilmeyenlere tanıtmaya çalışmak gibi bir görevi olduğu ifade edilmiştir ${ }^{272}$.

\section{1-Demokrasi Terbiyesi}

Diğer taraftan dönemin sonlarına doğru, okullarda demokrasi terbiyesi verilmesi çağrıları da başlamıştır. 1949 yılında bir milletvekili, ülkede demokrasinin yerleşmesinde okulların fonksiyonundan bahsetmiştir"273: "Demokrasi için her şeyden evvel demokrat vatandaşlar yetiştirmek lâzımdır ve demokrasi buna bağlıdır. Bu mefkûrenin gerçekleşebilmesi için okullarımız, sırf tedris müessesesi olmaktan çıkarılarak terbiye müessesesi haline getirilmelidir ve düşünme kabiliyetini haiz vatandaşlar yetiştirilmelidir. Kendi kendine düşünüp karar verebilen, siyasette demagoga, yalancıya, müfteriye kanmayan, iyiyi kötüden ayırabilen, kendini istismar ettirmeyen bir vatandaş kitlesi, demokrasinin gelişip semere vermesi ve bekası için ilk hayatî bir şarttır." 1950 yılında bu konuda diğer bir milletvekili, "Millî Ĕgitim sahasında, umumî meslekler mevzuubahis olduğu zaman, bugünün gidişine göre, başta demokratik terbiye gelmektedir. Buna dair müfredatta, tamimlerde ve emirlerde ileri adımlar atılmıştır. Ancak demokratik terbiye, mekteplerde bir metod meselesidir. İşi bu zaviyeden Millî Ĕ̈itim Bakanlığının tetkik edip ona göre tedbir alması lâzımdır" sözleriyle dikkat çekmiştir ${ }^{274}$. Başka bir milletvekili de, "Beş yıldır demokrasiye girdigimiz halde ilk ve ortaokullarda okunan kitaplar tek parti zihniyeti ile yazılmıştır. Demokratik devre girdiğimize göre okuma, yurt bilgiler kitaplarında demokrasi eğitiminin yer alması lâzımdır" sözleriyle demokrasi konusundaki hassasiyeti dile getirmiştir ${ }^{275}$.

\section{2-Ahlâk Eğitimi}

Okulların diğer bir fonksiyonunun da ahlâk eğitiminin yapıldığı yer olmasıdır. Bu husus, “... mektepte ahlâk deyince, maarifte ahlâk deyince, yalnız kitapta ve derste ahlâk, sözde ahlâk anlamamalıyız. Mektep doğrudan doğruya kendi havası, kendi yaşayışı itibarı ile ahlâk kaynağı olmalıdır" sözleriyle ifade edilmiştir ${ }^{276}$. Millî Eğitim Bakanı da Türk talebesinin ahlâk şiarını şu 7 maddede saymıştır ${ }^{277}$ :

1-Doğru sözlüdür,

\footnotetext{
${ }^{269}$ Saffet Tuncay (Siirt), 22.05.1945, TBMM,TBMM TD (7. Dönem), Cilt:17, s.251.

${ }^{270}$ Mehmet Fahrettin Ecevit (Kastamonu), 22.05.1945, TBMM,TBMM TD (7. Dönem), Cilt:17, s.251.

${ }^{271}$ Basın ve Yayın Umum Müdürü N. V. İlkin, 18.12.1945, TBMM,TBMM TD (7. Dönem), Cilt:20, s.187.

${ }^{272}$ Şükrü Sökmensüer (Erzurum), 22.05.1945, TBMM,TBMM TD (7. Dönem), Cilt:17, s.248.

${ }^{273}$ Reşat Aydınlı (Denizli), 25.02.1949, TBMM,TBMM TD (8. Dönem), Cilt:16, s.639.

${ }^{274}$ Emin Soysal (Maraş), 17.02.1950, TBMM,TBMM TD (8. Dönem), Cilt:24, s.808-809.

${ }^{275}$ Salih İnankur (İçel), 18.02.1950, TBMM,TBMM TD (8. Dönem), Cilt:24, s.828.

${ }^{276}$ Nevzat Ayas (Bursa), 25.05.1939, TBMM,TBMM ZC (6. Dönem), Cilt:2, s.247.

${ }^{277}$ Maarif Vekili Hasan Âli Yücel (İzmir), 27.05.1941, TBMM,TBMM ZC (6. Dönem), Cilt:18, s.219-220.
}

\section{History Studies}


2- Devlete itaat eder,

3- Öğretmenini ana baba bilir,

4- Arkadaşlarını sever,

5- Yurdunu ve milletini sever,

6- Sosyal faaliyetlerde bulunur,

7- Spor, kültür faaliyetleri yapar.

Okullarda okuyan kız çocuklarına meslek sahibi olmalarının yanında anne olacakları hususunun da telkin edilmesi üzerinde durulması istenmiştir ${ }^{278}$. Yine k1z öğrencilere ipekli çorap giydirilmesi ${ }^{279}$ ve okul müsamerelerinde makyaj yapılması eleştirilmiş ${ }^{280}$; bazı milletvekilleri tarafindan da kız öğrencilere okullarda dans dersleri verilmesi istenmiştir ${ }^{281}$.

\section{3-Eski Eserlerin Korunması}

30 Kasım 1925 tarih ve 677 sayılı Tekke ve Zaviyelerle Türbelerin Seddine ve Türbedarlıklar ile Birtakım Unvanların Men ve İlgaına Dair Kanun ile türbe, tekke ve zaviyelerin kapatılmıştır ${ }^{282}$.Ancak 1950 ve 1990 yıllarında yapılan değişikliklerle türbelerden Türk büyüklerine ait olanlarla büyük san'at değeri bulunanların Kültür Bakanlığı tarafindan umuma açılacağ 1 hükme bağlanmıştır.

Özellikle İstanbul'da yeni yollar ve binalar yapılırken kazı çalışmaları sırasında eski eserlere rastlanması olaylarının artması üzerine Millî Eğitim Bakanlığı, 1939 yılında, bu eserlerin yer alacağı bir harita yaptırmaya karar vermiştir ${ }^{283} .1943$ yılından itibaren de pek çok eski eser ve türbelerin tamir edilerek açılması talepleri gündeme getirilmiştir. İlk olarak Topkapı Sarayının tamirine başlanmıș, 1941 yılından itibaren bu iş için 500.000 lira harcanmıştır ${ }^{284}$. Daha sonra İstanbul'daki Yahya Efendi, Barbaros Hayrettin Paşa, Galata Mevlevîhanesi, Humbaracı Ahmet Paşa ve Ankara' lı İsmail Efendi türbelerinin durumunun ne olduğu sorulmuştur ${ }^{285} .1945$ yılında, 30 bin liralık bir tahsisat ile, aralarında Gazi Osman Paşa, II. Bayezit ve Selçuk Hatun türbelerinin de bulunduğu 5-6 türbe tamir ettirilmiştir ${ }^{286}$. Bunlardan başka Hazreti Hâlid, Koca Reşit Paşa, Rumî Mehmet Paşa, Nakkaş Hasan Paşa, Hüsrev Paşa, Kaptan Mustafa Paşa türbelerinin de tamir edileceği Millî Eğitim Bakanı tarafından açıklanmıştır ${ }^{287} .1949$ yılında Fatih Sultan Mehmet, Üçüncü Selim, İkinci Mahmut, Yavuz Sultan Selim, Kanunî Sultan Süleyman, Reşit Paşa, Gazi Osman Paşa türbelerinin ${ }^{288}$; 1950 yılında da Tezveren Baba, Köprülü Mehmet Paşa, Fazıl Ahmet Paşa türbelerinin açılması

\footnotetext{
${ }^{278}$ Şehime Yunus (İzmir), 25.05.1939, TBMM,TBMM ZC (6. Dönem), Cilt:2, s.265.

${ }^{279}$ Osman Şevki Uludağ (Konya), 25.05.1939, TBMM,TBMM TD (7. Dönem), Cilt:20, s.311.

${ }^{280}$ Osman Şevki Uludağ (Konya); 25.05.1939, TBMM,TBMM ZC (6. Dönem), Cilt:2, s.245.

${ }^{281}$ Hakkı Kilıçoğlu (Muş); 26.05.1937, TBMM,TBMM ZC (5. Dönem), Cilt:18, s.253-254.

${ }^{282}$ Resmî Cerîde, 13 Aralık 1925, Sayı:243, s.735.

${ }^{283}$ Maarif Vekili Hasan Âli Yücel (İzmir), 25.05.1939, TBMM,TBMM ZC (6. Dönem), Cilt:2, s.269.

${ }^{284}$ Hikmet Turan Dağlıŏglu (Antalya), 26.05.1943, TBMM,TBMM ZC (7. Dönem), Cilt:2, s.239.

${ }^{285} 25.05 .1944$, TBMM,TBMM ZC (7. Dönem), Cilt:10, s.264-266.

${ }^{286}$ Hikmet Turan Dağlığlu (Antalya); 24.12.1945, TBMM,TBMM TD (7. Dönem), Cilt:20, s.316.

${ }^{287}$ Millî Eğitim Bakanı Hasan Âli Yücel (İzmir), 24.12.1945, TBMM,TBMM TD (7. Dönem), Cilt:20, s.342.

${ }^{288}$ Hamdullah Suphi Tanriöver (İstanbul), 25.02.1949, TBMM,TBMM TD (8. Dönem), Cilt:16, s.664.
}

\section{History Studies}


istenmiştir ${ }^{289}$.Yine 1950 yılında Ayasofya Müzesi'nin tamire muhtaç olduğu dile getirilmiştir ${ }^{290}$.

Konya'daki Karatay Medresesi, Alâaddin Camii, Sahipata Medrese Camii, Sırçalı Mescit ve İnce Minareli Camiin tamire muhtaç olduğu ifade edilmiştir ${ }^{291}$. Eskişehir'de Porsuk Barajı inşaatı altında kalacak olan Türk büyüğü Ahmet Beşirî türbesinin,bulunduğu yerden kaldırılması ve uygun bir yere nakli istenmiş, fakat tahsisat yokluğundan mümkün olmamışıır ${ }^{292}$. Ayrıca Niğde, Ulukışla, Konya, Aksaray, Nevşehir'deki Selçuklu ve Karamanlılar'dan kalan tarihî eserlerin de koruma altına alınması istenmiştir ${ }^{293}$. Suriye'de Caber Kalesinde bulunan Süleyman Şah Türbesi'nin harap halde bulunduğu ve burasının da tamir edilmesi gerektiği, çünkü Süleyman Şah'ın Türk milletinin ebediyete kadar yaşayacak olan ruh abidesi olduğu vurgulanmıştır ${ }^{294}$.

$\mathrm{Bu}$ eserlerden başka, Şer'iyye Sicilleri ve Topkapı Sarayı'ndaki milletimizin iktisadî, sosyalve askerî bakımlardan tarih kaynakları olan belgelerin bir arşiv oluşturularak orada muhafazası ve araştırmacıların isitifadesine açılması talepleri de dile getirilmiştir ${ }^{295}$. Mevlâna Mesnevîsi ve diğer Türk klâsik eserlerinin yayınlanması talepleri de dile getirilmiş ${ }^{296}$; Millî Eğitim Bakanı Hasan Âli YÜCEL, Mesnevî’den başka Kutadgu Bilig, Tuhfetüzzekiyye gibi gerçek bir anıt hükmündeki eserlerin bugünkü dilimizle basıldığını ifade etmiştir ${ }^{297}$.

\section{Sonuç}

Cumhuriyet'in ilânı ile birlikte eğitim alanında, Türk tarihinde şimdiye kadar görülmemiş bir ölçüde eğitim hamlesi gerçekleştirilmiştir. Okullaşma oranları her yıl artarak, okul ve öğrenci sayıları 1950 yılında 17.000 ilkokul, 1.625 .000 öğrenci; 215 ortaokul, 60.000 öğrenciye ulaşmıştır. 1946 yılında 53 lise ve buralardan mezun olanların sayısı 5000'e yaklaşmıştır. Meslekî eğitim veren liseler olarak, 1937 yılı itibarıyla Millî Eğitim Bakanlığına bağlı erkek sanat okulları, akşam erkek sanat okulları, kız enstitüleri, akşam kız sanat okulları, kız erkek öğretmen okulu, orta ticaret okulları, birinci ve ikinci devreli ticaret liseleri, akşam ticaret okulları, yapı ustası okulu, terzilik ve kürkçülük okulu gibi meslek okulları açılmıştır. 1924 yılında 29 merkezde İmam Hatip Mektepleri açılmıştır.

Okul çağını geçmiş geniş halk kitlelerinin eğitimi için 1928 yılında "Millet Mektepleri" açılmış; 1928-1935 yılları arasında Millet Mekteplerinin şehir ve köylerde açılan bütün kademelerinde eğitim alan vatandaş sayısı 2.500.000'i geçmiş; belge alan vatandaş sayısı 1.878.676'ya kadar ulaşmıştır. Halk Mektepleri ve Gece Kurslarında gündüz işlerinde çalışan vatandaşlara geceleri eğitim verilmiştir. 1928 yılı itibarıyla bu kurslar 12 yerde açılmış ve 493 öğrenciye hizmet vermiştir. Köy öğretmeni ihtiyacını karşılamak üzere 1940-1948 yılları arasında ülkenin değişik bölgelerinde 21 tane Köy Enstitüsü açılmış ve Köy Enstitülerinden toplam 15.000 kadar öğretmen, 2.000 kadar sağlıç̧ı yetişmiştir. 1933 Üniversite Reformu ile Ankara ve İstanbul'da yeni üniversite ve fakülteler açılarak yüksek öğretim kurumlarının imkânları genişletilmiştir.

\footnotetext{
${ }^{289}$ Nazım Poroy (Tokat), 17.02.1950, TBMM,TBMM TD (8. Dönem), Cilt:24, s.798.

${ }^{290}$ Kasım Ener (Seyhan),25.02.1949, TBMM,TBMM TD (8. Dönem), Cilt:16, s.667.

${ }^{291}$ Sedat Çumralı (Konya), 25.02.1949, TBMM,TBMM TD (8. Dönem), Cilt:16, s.655.

${ }^{292}$ Ahmet Bozbay (Kütahya), 25.02.1949, TBMM,TBMM TD (8. Dönem), Cilt:16, s.658.

${ }^{293}$ İbrahim Refik Soyer (Niğde), 18.02.1950, TBMM,TBMM TD (8. Dönem), Cilt:24, s.829-831.

${ }^{294}$ Hikmet Turan Dağlıŏlu (Antalya), 24.12.1945, TBMM,TBMM TD (7. Dönem), Cilt:20, s.385

${ }^{295}$ Hikmet Turan Dağlığlu (Antalya), 26.05.1943, TBMM,TBMM ZC (7. Dönem), Cilt:2, s.240.

${ }^{296}$ Fuat Gökbudak (Konya), 25.05.1939, TBMM,TBMM ZC (6. Dönem), Cilt:2, s.253.

${ }^{297}$ Maarif Vekili Hasan Âli Yücel (İzmir), 26.05.1939, TBMM,TBMM ZC (7. Dönem), Cilt:2, s.253.
}

\section{History Studies}


Eğitim personeli alanında da gelişmeler kaydedilmiştir. 1950 yılı itibarı ile Millî Eğitim Bakanlığı emrinde 47.600 öğretmenin çalışmakta olduğu; ayrıca 7.400 kadar da memur ve müstahdem bulunduğu, böylece toplam 55.000 kişilik bir personel kadrosu bulunduğu ifade edilmiştir. Bunlardan başka "Köy Öğretmeni", "Köy Ĕgitmeni" kadroları ihdas edilerek eğitim hizmetlerinin personel ihtiyacı karşılanmaya çalışılmıştır.

1947 yılı itibariyle, toplam 463 Halkevi ve 4110 Halkodası açılmak suretiyle halk eğitimine ağırlık verilmiştir.

Din eğitimi alanında da köy hocası ve cami görevlileri yetiştirecek çalışmalar yapılmıştır. Müzik, heykel, tiyatro gibi güzel sanat alanlarında eğitim verecek kurumlar oluş̧urulmuştur.

Bütün bunların sonunda 1924 yılında yüzde 2-3 olan okuryazar oranları 1927 nüfus sayımında yüzde 11, 1935 yılında yüzde 20,4, 1947 yılında yüzde 36,9, 1950 yılında yüzde 40 olmuştur.

\section{KAYNAKÇA}

\section{a- Türkiye Büyük Millet Meclisi Zabıt Cerîdesi ve Tutanak Dergisi}

Türkiye Büyük Millet Meclisi Zabıt Ceridesi (1.Dönem),Cilt:13, Ankara,1958.

Türkiye Büyük Millet Meclisi Zabıt Ceridesi (2.Dönem),Cilt:6, Ankara,1968.

Türkiye Büyük Millet Meclisi Zabıt Ceridesi (2.Dönem),Cilt:25, Ankara.

Türkiye Büyük Millet Meclisi Zabıt Ceridesi (2.Dönem),Cilt:31, Ankara.

Türkiye Büyük Millet Meclisi Zabıt Ceridesi (3.Dönem),Cilt:3, Ankara.

Türkiye Büyük Millet Meclisi Zabıt Ceridesi (3.Dönem),Cilt:19, Ankara, 1933.

Türkiye Büyük Millet Meclisi Zabıt Ceridesi (4.Dönem),Cilt:9, Ankara, 1932.

Türkiye Büyük Millet Meclisi Zabıt Ceridesi (4.Dönem),Cilt:15, Ankara, 1933.

Türkiye Büyük Millet Meclisi Zabıt Ceridesi (4.Dönem),Cilt:22, Ankara, 1934.

Türkiye Büyük Millet Meclisi Zabıt Ceridesi (5.Dönem),Cilt:3, Ankara, 1935.

Türkiye Büyük Millet Meclisi Zabıt Ceridesi (5.Dönem),Cilt:11, Ankara, 1936.

Türkiye Büyük Millet Meclisi Zabıt Ceridesi (5.Dönem),Cilt:18, Ankara, 1937.

Türkiye Büyük Millet Meclisi Zabıt Ceridesi (5.Dönem),Cilt:25, Ankara, 1938.

Türkiye Büyük Millet Meclisi Zabıt Ceridesi (6.Dönem),Cilt:2, Ankara, 1939.

Türkiye Büyük Millet Meclisi Zabıt Ceridesi (6.Dönem),Cilt:11, Ankara, 1940.

Türkiye Büyük Millet Meclisi Zabıt Ceridesi (6.Dönem),Cilt:18, Ankara, 1941.

Türkiye Büyük Millet Meclisi Zabıt Ceridesi (6.Dönem),Cilt:25, Ankara, 1942.

Türkiye Büyük Millet Meclisi Zabıt Ceridesi (7.Dönem),Cilt:2, Ankara, 1943.

Türkiye Büyük Millet Meclisi Zabıt Ceridesi (7.Dönem),Cilt:3, Ankara, 1943.

Türkiye Büyük Millet Meclisi Zabıt Ceridesi (7.Dönem),Cilt:10, Ankara, 1944. 
Türkiye Büyük Millet Meclisi Tutanak Dergisi (7.Dönem),Cilt:17, Ankara, 1945.

Türkiye Büyük Millet Meclisi Tutanak Dergisi (7.Dönem),Cilt:20, Ankara, 1946.

Türkiye Büyük Millet Meclisi Tutanak Dergisi (8.Dönem), Cilt:3, Ankara, 1947.

Türkiye Büyük Millet Meclisi Tutanak Dergisi (8.Dönem),Cilt:8, Ankara, 1948.

Türkiye Büyük Millet Meclisi Tutanak Dergisi (8.Dönem),Cilt:16, Ankara, 1949.

Türkiye Büyük Millet Meclisi Tutanak Dergisi (8.Dönem), Cilt:24, Ankara, 1949.

Türkiye Büyük Millet Meclisi Tutanak Dergisi (11.Dönem),Cilt:7, Ankara, 1959.

\section{b- Resmî Cerîde ve Resmî Gazeteler}

Resmî Cerîde, 13 Aralık 1925, Sayı:243.

Resmî Cerîde, 3 Nisan 1926, Sayı:338.

T.C.Resmî Gazete, 3 Kasım 1928, Sayı:1030.

T.C. Resmî Gazete, 6 Haziran 1933, Sayı:2420.

T.C. Resmî Gazete, 24 Haziran 1937, Say1:3629.

T.C. Resmî Gazete, 31 May1s 1948, Sayı:6919.

T.C. Resmî Gazete, 2 Şubat 1948, Sayı:6821.

T.C. Resmî Gazete, 18 Mart 1950, Sayı:7460.

T.C. Resmî Gazete, 29 Mart 1950, Sayı:7469.

\section{c- Makale ve Kitaplar}

ATAMAN, Sadi Yaver ,Atatürk ve Türk Musıkîsi, Kültür Bakanlığı Yayınları, Ankara, 1991.

AYDAR, Hidayet, "Kur'an”, Türkiye Diyanet Vakfi İslâm Ansiklopedisi, Cilt: 26, Ankara,2002.

AKYÜZ, Yahya,Türk Eğitim Tarihi, Kültür Koleji Yayınları, İstanbul, 1993.

Akşam, 6 Şubat 1932.

ALBAYRAK, Mustafa, "Millet Mekteplerinin Yapısı ve Çalışmaları (1928-1935)", Atatürk Araştırma Merkezi Dergisi, Temmuz 1994, Cilt:X, Sayı:29, s.471-483.

ATAÜNAL, Aydoğan,Türkiye'de İlkokul Öğretmeni Yetiştirme Sorunu (1923-1994), Millî Eğitim Bakanlığı Yayını, Ankara, 1994.

BAŞAR, Erdoğan, Millî Eğitim Bakanlarının Eğitim Faaliyetleri (1920-1960), Millî Eğitim Basımevi, Ankara, 2004.

Cumhuriyet Dönemi Türkiye Ekonomisi 1923-1978, Akbank Kültür Yayını, İstanbul,1980.

ERDEM, Çiğdem, “Cumhuriyet Yönetiminin 1930’lu Yıllarda Köyde ve Köylülükte

Dönüşümü Gerçekleştirme İsteğinin Bir Aracı Olarak Köy Eğitmen Kursları”, Gazi

Üniversitesi İktisadî ve İdarî Bilimler Fakültesi Dergisi, Cilt:10, Sayı, s, 2008, s.187-200. 
ERGIN, Osman,Türk Maarif Tarihi, Cilt:5, İstanbul, 1977.

ESKİ, Mustafa, "Mustafa Necati”, Atatürk Araştırma Merkezi Dergisi, Temmuz 1996, Cilt: XII, Say1: 35, s. 463-481.

EVSİLE, Mehmet, Millî Mücadele Sirasında Anadolu'da Günlük Hayat, E Yazı Yayınları, Samsun, 2015.

HAYDAROĞLUPOLAT, İlknur,Osmanlı İmparatorluğu'nda Yabancı Okullar, Kültür Bakanlığı Yayını, Ankara, 1990.

KALAYCI, Nurdan ; Cumhuriyet Döneminde Illköğretim Hükümet Programları ve Uygulamalar, Milli Eğitim Gençlik ve Spor Bakanlığı Yayınları: 762, İstanbul, 1968.

KORKMAZ, Zeynep, “Alfabe Devriminin Türk Toplumu Üzerindeki Sosyal ve Kültürel Etkileri”, Turkish Studies, Volume 4/3 Spring 2009, s.1469-1480.

KUL, F.Nurşen, "Erken Cumhuriyet Dönemi İlkokul Binaları", Mimarlık Dergisi, Say1:360, Temmuz Ağustos 2011, s. 66-71.

NAMAL, Yücel-Tunay KARAKÖK, “Atatürk ve Üniversite Reformu (1933)”, Yükseköğretim ve Bilim Dergisi, Cilt:1, Sayı:1, Nisan 2011, s. 27-35.

ÖCAL, Mustafa; “Cumhuriyet Döneminde Türkiye'de Din Eğitimi ve Öğretimi”, Uludă̆ Üniversitesi Illâhiyat Fakültesi Dergisi, Cilt:7, Say1:7, s. 241-268.

ÖZDEMİR Yavuz-Elif AKTAŞ; “Halkevleri (1932'den 1951'e)”, A.Ü.Türkiyat

Araştırmaları Enstitüsü Dergisi [TAED] 45, Erzurum, 2011, s.235-262.

SÖNMEZ, Şinasi; "Köy Eğitmenleri ve Kadro Sorunları", Karaelmas Journal of EducationalSciences, Cilt:1, Say1:1, 2013, s. 50-61.

ŞiŞMAN, Adnan, XX. Yüzyıl Başlarında Osmanlı Devleti'nde Yabancı Devletlerin Kültürel ve Sosyal Müesseseleri, Atatürk Araştırma Merkezi yayını, Ankara, 2006.

TEZEL, Yahya S,Cumhuriyet Döneminin İktisadî Tarihi (1923-1950), Türkiye İş Bankası Kültür Yayını, İstanbul, 2015.

TÜRKMEN, İsmet; Kastamonu Halkevi Kastamonu Halkevi Ve Türkiye' in Modernleşme Sürecine Katklarl 1932 1951, Berikan Yayınevi, Ankara 2013.

ÜNAL, Yenal, "İdare-i Umumiye-i Vilâyet ve İdare-i Hususiye-i Vilâyet Kanunları", Tarih Okulu, Yaz 2009, Sayı: IV, s.77-101. 